Article

\title{
Beyond Gathering the 'Low-Hanging Fruit' of Green Technology for Improved Environmental Performance: an Empirical Examination of the Moderating Effects of Proactive Environmental Management and Business Strategies
}

\author{
Beatriz Forés \\ Business Management Department, Universitat Jaume I, 12071 Castellón, Spain; bfores@uji.es
}

Received: 24 September 2019; Accepted: 7 November 2019; Published: 9 November 2019

\begin{abstract}
This study draws on the natural resource-based view and the dynamic capabilities theory to analyse the effects of green technology, proactive environmental management and business strategy on environmental performance. This paper offers a novel analysis of the direct effect of the integrated use of green technology on environmental performance, considering a non-linear relationship between them, and how this impact can be leveraged through a formal proactive environmental planning, coordination and control system, and a defined business strategy. In order to test the research hypotheses, multiple linear regression was used on a sample of 446 Spanish tourism firms. The results confirm a non-linear relationship between green technology and environmental performance. They also indicate the importance of defining a clear, proactive environmental management and prospector strategy to achieve more efficient products/services, processes and technologies, with minimal environmental impact. This research also provides some insights into the moderating effect exerted by proactive environmental management in terms of strengthening the relationship between green technology and environmental performance. In addition, the analysis confirms that whereas defender strategies reduce the impact of green technology on environmental performance, analyser and prospector strategies enhance its influence. These results can be used to offer a series of guidelines for both private and public agents in the tourism sector.
\end{abstract}

Keywords: green technologies; environmental performance; proactive environmental management; prospector strategy; defender strategy; analyser strategy

\section{Introduction}

In recent decades, the natural environment has changed the global competitive arena, and organisations have been prompted to reconsider their environmental impact [1]. Growing demands from diverse stakeholders, such as customers or non-profit organisations, along with new environmental regulations, have encouraged managers to adopt more sustainable practices in order to preserve natural resources and mitigate climate change [2].

In this context, firms' environmental performances have sparked major interest from academia, business practitioners and the general public [3]. Although research on environmental challenges has traditionally focused on the manufacturing industry, recent data on pollution produced by the tourism industry and its estimated exponential future growth [4] have made it the focus of a growing number of recent research papers (e.g., [1,5-9]). Specifically, the study by Lenzen et al. [4] on 160 countries estimates that tourism accounts for approximately $8 \%$ of global greenhouse gas emissions, of which $12 \%$ are from air travel; this amount is expected to rise by $40 \%$ by 2025 if there are no changes 
in politics or personal habits. Another factor that makes the tourism industry worthy of analysis in the environmental performance literature is the high dependence on natural resources and the surrounding environment of competing tourism products [10]. In this vein, Zhu et al. [11] point out that most energy use in the tourism industry is still reliant on traditional fossil fuels.

Considering that the sustainability of the tourism industry depends in part on generating new development patterns, this study contributes to the analysis of the determinants of tourism firms' environmental performance relating to technologies, management systems and business strategies. It also examines how the effect of green technology on environmental performance may be leveraged through the adoption of a proactive environmental management and different business strategy types.

Environmental performance can involve a variety of aspects, such as preventing environmental pollution, reducing waste, minimising the consumption of materials, energy and water, enhancing equipment efficiency, maximising the use of renewables, extending product life and ensuring that both resources and products can be recycled [12]. Previous literature demonstrates that improving environmental performance also enables firms to achieve economic and social benefits [2], that is, it improves their sustainability performance in terms of the Triple Bottom Line (TBL) concept proposed by Elkington [13].

Good environmental performance offers advantages in terms of cost savings, productivity, employee motivation and satisfaction, access to new markets and differentiation, stemming from firms' enhanced reputation and the quality and environmental characteristics of their products and services [2,5]. According to Chen and Chang [14], consumers are eager to purchase environmentally-responsible, green products; for instance, these authors show that $83 \%$ of Brazilians and $53 \%$ of Americans are willing to pay a higher price to purchase green products. Nevertheless, despite consumers' increasingly positive attitude towards environmentally-friendly products, in the tourism sector, it seems hard to shake the idea that the environmental cost should be assumed by the business owner $[5,15]$. It thus appears clear that in the tourism sector, practices aimed at improving environmental performance must originate from within the firm itself [6].

Information Technology (IT) can be both a problem and a solution when it comes to environmental performance [16,17]. On the one hand, IT use is responsible for approximately $2 \%$ of global greenhouse gas emissions, due to the electricity required to run it $[16,18]$. On the other hand, it has also been argued that IT has been the greatest force for productivity improvement and efficiency in the last half century [19], thus offering opportunities for firms to pursue better environmental performance [3,20].

Despite the importance of green technology in improving environmental performance, the strategic management literature has failed to explain whether and how green technology can contribute to this performance [17]. The few existing qualitative (e.g., [17,19,21]) and empirical research papers (e.g., $[3,22]$ ) seem to confirm that these technologies have a positive effect on the achievement of environmental aims.

However, certain theoretical (e.g., [16]) and empirical studies (e.g., [23-25]) highlight both positive and negative effects of the adoption or use of these technologies on environmental performance. This has led to a degree of controversy within academia regarding the sign of the effect of firms' level of green technology adoption, which no research to date appears to have resolved; indeed, to the best of our knowledge there is no empirical study that explores the possibility of a non-linear relationship between the two. This study applies the principles of the natural resource-based view [26] and dynamic capabilities theory $[27,28]$ in an attempt to fill that gap, and to determine the extent to which this adoption or usage of green technology has a positive influence on environmental performance.

A further aspect which remains unclear is the potential channels through which the effect of green technology on environmental performance may be leveraged, and under what conditions this impact occurs. The literature appears to point to the adoption of proactive environmental management (e.g., [2,26,29]) and a prospector strategy (e.g., [30-32]) as key determinants of environmental performance. Considering the strong divisions within the existing literature, the second aim of 
this research is to confirm the direct impact on environmental performance of implementing proactive environmental management and a prospector strategy.

Furthermore, previous theoretical [20] and empirical [3,22,33] studies have also examined the need for proactiveness in environmental management and strategy formulation in order to improve and sustain the competitive advantages gained from the implementation of IT for environmental aims. However, there is limited empirical evidence of the specific moderating effect that proactive environmental management and a prospector strategy have on the relationship between green technology and environmental performance.

Considering the non-linear relationship established between the level of green technology adoption and environmental performance, our analysis of the moderating effects involves an examination of their contribution to firms' ability to better exploit green technology to improve environmental performance, that is, to achieve a higher point of maximum efficiency in terms of the use of green technology to improve environmental performance.

Therefore, after analysing the direct effects, this study attempts to address this other gap in the literature. The analysis of the moderating effect of a prospector strategy will be extended to include the other strategy types: the defender strategy, which is the opposite of the prospector; and the analyser strategy, which lies somewhere between the defender and the prospector. This comparison will determine the extent to which the different business strategy types are capable of leveraging technologies, resources and capabilities to achieve environmental aims. This comparative analysis also represents a significant step forward in the literature on the topic, since most related studies focus on examining the most differing strategy types, overlooking the strategic advantages of analyser companies.

Finally, having identified the main contributions of this study, it should be noted that the research focuses on the tourism sector. While the existing research on the adoption of green technology in the tourism sector has yielded some promising evidence, it remains very limited and unstructured. Previous descriptive studies, primarily focusing on the hotel sector, seem to point to a gradual yet growing trend in the implementation of these technologies to improve the deployment of environmental projects/programmes $[7,10]$.

This sector was chosen not only because of the shortage of research work in this area, but also due to public concerns regarding its substantial direct and indirect environmental effects [6,29], its major socio-economic impact and the expected exponential growth of this sector in developed economies such as Spain, which is the context of our analysis. The tourism sector is directly or indirectly responsible for generating $11.7 \%$ of Spain's gross domestic product and $12.8 \%$ of its total employment [34].

In order to test the research hypotheses, multiple linear regression was used on a sample of 446 Spanish tourism firms. The results confirm a non-linear relationship between the level of green technology adoption and environmental performance. They also indicate the importance of defining a clear, proactive environmental management and prospector strategy to achieve more efficient products/services and processes with minimal environmental impact.

This research also provides insights into the moderating effect exerted by proactive environmental management on the strategic implementation of green technologies to improve environmental performance. It confirms that whereas defender strategies reduce the impact of green technology on environmental performance, prospector and analyser strategies enhance it. In addition, the focus on different activities in the tourism sector (hotels, restaurants, travel agencies and tour operators, transport companies and complementary offers) allows a better understanding of the approach to environmental protection adopted in each subsector. These results can be used to offer a series of guidelines for both private and public agents in the tourism sector that underscore the importance of promoting proactive and innovative environmental behaviour.

In order to achieve the proposed objectives, the rest of this article is structured as follows: firstly, the theoretical framework is explored and the hypotheses are formulated; secondly, our sample, variable selection and methodology are described; thirdly, the results obtained are presented; and 
finally, a discussion of the results is presented, along with the managerial and public implications, the limitations of the study and future research lines.

\section{Theoretical Framework and Hypotheses}

The rapid depletion of natural resources and growing public awareness of the environmental degradation that has occurred over recent decades has made environmental performance one of the key objectives of contemporary business organisations [23]. This represents a departure from the traditional single objective of economic performance, although there is undeniably a recursive relationship between these two types of outcomes [26]. Environmental performance creates value and quality through the achievement of energy, material and technological efficiency. Moreover, the reduction of negative environmental impacts and the protection of the environment for future generations also contribute to societal wellbeing [35]. Therefore, the drivers of a firm's environmental performance are of crucial interest to all current and future stakeholders because they help ensure the long-term health and survival of the business.

In this context, a new paradigm of management for sustainable development has emerged, entailing major changes in current production systems and the use of natural resources [36]. A number of studies have attempted to identify which resources and capabilities enable an organisation to adapt, change and innovate to meet new environmental challenges, under the framework of the natural resource-based view (e.g., [3,37-39]).

The natural resource-based view (NRBV) further develops the resource-based view [40] by taking into account the natural environment in the relationship between a firm's assets-i.e., its resources and capabilities-and its economic and environmental performance [26]. Central to this approach is the notion that natural resources will be increasingly constrained in the future, and only those firms that can manage environmental challenges will be able to sustain or achieve a competitive advantage. A more efficient use of environmental resources means a better utilisation of inputs, which also improves the firm's competitive advantage [41].

Another extension of the RBV, which focuses on firms' capabilities to respond and continuously adapt to environmental and social changes in their surroundings, is the dynamic capabilities theory [38,42-44]. This theory holds that firms' dynamic capabilities to integrate, build and reconfigure internal and external resources and capabilities enable them to sustain their competitive advantage through innovation in rapidly-changing environments [27,28]. A capability is considered dynamic when it enhances the firm's ability to identify opportunities and threats, make decisions and solve problems, through modifications to existing assets [45].

In contrast to the NRBV, which takes a static approach to understanding how organisations confront environmental imperatives in changing environments [45], assuming firms' exclusive reliance on their existing base of resources and capabilities, dynamic capabilities theory is centred on the reconfiguration, adaptation and continual modification of the firm's assets through knowledge acquisition and generation $[27,28]$. Dynamic capabilities theory can thus provide a valuable perspective that complements the NRBV in the study of complex and dynamic environments, such as those in which firms seek to improve their environmental performance [46].

Both the NRBV and dynamic capabilities theory are used in the analysis of the relationships between green technology, proactive environmental management, certain business strategies and environmental performance [3,47].

At this point, we should define our main research variables. Green technology can be defined as the set of technologies incorporating the techniques and equipment used in product design, production and distribution, which enhance efficiency, reduce energy and water waste, and mitigate environmental problems $[7,33,48,49]$. There are a range of synonymous terms to refer to green technology, such as "clean technology", "pollution prevention technologies", "environmental technology" and "low-carbon technology" (see [50]). In the tourism sector, the most common green technologies include those used to achieve water and energy savings, intelligent buildings (for instance, equipped with wall 
insulation and glass laminating materials, motion sensors to improve insulation, energy-efficient light bulbs, a grey water recycling system for gardening and flushing toilets, air-conditioning or a heat recovery system, and solar-based renewable energy) and other industrial automation (intelligent conservation chambers, energy- and water-efficient kitchens and bathrooms, food composters to reduce food waste and recycling facilities for other types of solid waste such as plastics, glass, and paper etc.). Chan et al. [51] provides a comprehensive review of the most common green technologies and their specific key components and areas of application in the hospitality sector. Key challenges include the investment in green-building constructions that make better use of solar, wind and geothermal power technology, efficient refrigeration, air conditioning and heating.

Proactive environmental management can be defined as regular patterns of voluntary practices, integrated into each corporate management function, which go beyond regulatory requirements; for instance, practices involving waste reduction, the minimisation of water and energy consumption, and the prevention of pollution $[29,52]$. Proactive environmental management provides support for management and employees through communication, transparency and enhancement of environmental values, as well as planning and control mechanisms [53].

Prospector strategy, as it relates to sustainability, involves redefining the business and innovating in products and processes to prevent waste and pollution, and to allow firms to respond to environmental changes [54]. Rather than seeking out standardised, easy-to-imitate solutions, prospector strategies rely on managerial discretion and the interpretation of environmental opportunities and threats [1]. This type of strategy thus enables the integration of environmental principles into the overall firm strategy (such as the objectives, vision and/or mission).

From the NRBV perspective, green technology and the associated practices and skills are considered a source of competitive advantage in environmental terms due to their contribution to making manufacturing processes more efficient and sustainable, and the development of green products [55].

Nevertheless, as with other IT, green technologies do not meet the criteria required to be considered a source of sustainable competitive advantage since they are not scarce and are easy to imitate [56]. A company's IT infrastructure (i.e., hardware, software, databases and networks) can also be easily acquired by competitors or replicated by hiring qualified personnel [47].

The NRBV and, above all, dynamic capabilities theory underscore the idea that sustainable environmental performance entails not only technological but also organisational innovation; that is, achieving environmental aims entails changes in behaviours, culture, routines and operations, since it requires the management and coordination of complex human and technical skills in order to reduce environmental impacts and simultaneously maintain or increase the competitiveness of the firm [54]. However, as pointed out above, the dynamic capabilities approach goes a step further than the NRBV in (1) the identification of the capabilities that allow a firm to change and adapt its existing resources and capabilities to create and sustain environmental competitive advantages, and (2) the examination of the underlying processes through which these changes in the firm's assets are produced [28].

In this vein, one of the challenges that firm management currently faces when it comes to improving and sustaining competitive advantages based on green technology is to integrate it into a formal environmental planning, management and control system $[3,22,26,33]$ and ensure its alignment with a strategic direction aimed at exploration and innovation [30]. This means that the interface between green technology and environmental performance is reinforced by the heterogeneous presence of other resources and capabilities. According to this contingency or complementary assets approach to IT adoption [56,57], bundled assets create causal ambiguity and social complexity, and prevent the replication of assets that enable firms to enhance their environmental performance, in turn helping them to obtain a sustainable competitive advantage [58].

Both proactive environmental management and a prospector strategy integrate elements of sensing (through business ecosystem exploration and the collaboration and integration of internal and external stakeholders), seizing (through stakeholders' cooperation, knowledge dissemination and employee training 
and coordination) and reconfiguring processes (through the establishment of new objectives and managerial processes, new directions for resource allocation and employee cooperation and coordination) [28,42]. Therefore, they could be considered dynamic capabilities necessary for creating and sustaining a competitive advantage in environmental performance [42], above all in this new, dynamic and green competitive environment $[26,59]$. In fact, proactive environmental management fulfils the requirements-identified by Aragón-Correa and Sharma [54] in their definition of a prospector strategy as a dynamic capability—of relying on specific, path-dependent processes and being embedded within the organisation.

This study thus analyses the moderating effect of both proactive environmental management and prospector strategy on the relationship between green technology and environmental performance. As an extension of the analysis, the moderating effect of prospector strategy will be compared with that of the other strategic archetypes proposed by Miles and Snow [60]; namely, the defender and analyser strategies, with the reactor strategy taken as a reference.

Therefore, we apply both the NRBV and dynamic capabilities theory to analyse the direct effects of green technology, proactive environmental management and prospector strategy on environmental performance. Our study also considers the moderating effects of both proactive environmental management and certain business strategies (prospector, analyser and defender archetypes) on the relationship between green technology and environmental performance. In line with the above, the conceptual model is shown in Figure 1.

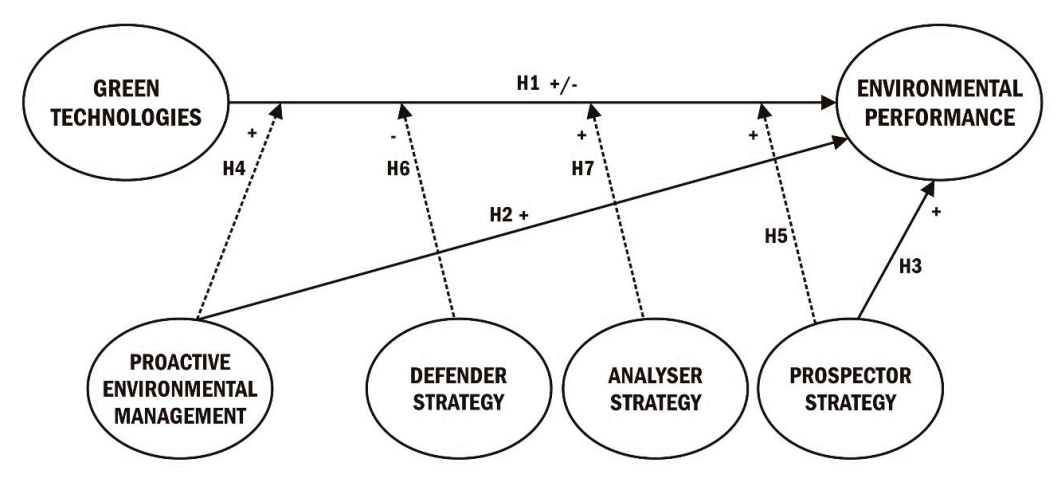

Figure 1. Conceptual framework.

\subsection{Direct Effects}

\subsubsection{Green Technology and Environmental Performance}

Climate change is one of the most pressing challenges facing society, requiring the prompt adoption of effective technological innovations in many sectors [61]. Over the past several years, green technology has thus become an integrated part of firms' environmental programmes [33].

The tourism industry is under severe pressure from consumers and society as a whole to comply with new green requirements. Tourism firms are also subject to strict environmental regulation [6], and even face pressure from business partners and the shareholders of their holding companies [7]. As a result, the industry has witnessed increasing implementation of this type of revolutionary technology for managing its operations [3]. Nevertheless, according to Chan et al. [7], the level of implementation of such technologies remains moderate compared to other sectors, with the authors identifying management's lack of specialised knowledge about its use as the main barrier to its implementation.

Various green technologies can be applied to reduce pollution and the use of toxic and hazardous resources in the product/service production process (above all, those from non-renewable resources), to cut the consumption of materials, energy and time in the service provision, to manage energy-consuming facilities (e.g., buildings), to control and improve equipment efficiency and to design new greener processes, products and services and redesign the existing ones so as to be more environmentally sustainable $[19,25,33]$. Green technologies are thus aimed at meeting human needs without depleting the planet's resources or degrading the ecosystem [59]. 
Despite the growing importance assigned to this topic in academia, especially in the field of business management, and in the public domain [3], the few publications on the subject are primarily opinion pieces, or qualitative and explorative studies (e.g., $[17,19,21])$. Recent empirical research papers, within a very fragmented and dispersed body of literature, highlight the impact of green technology on environmental performance (e.g., [3,22]) as well as social (e.g., [62]) and economic outcomes (e.g., [24,33]). Specifically regarding the hotel industry, some authors emphasise the importance of green technology for improving environmental performance through energy efficiency gains, the enhanced productivity of resources and business processes or innovation [63,64].

Although most green technologies are considered energy-efficient systems, it has also been postulated that the extensive adoption of green technology in the firm can lead to excessive power consumption and potential overuse of a firm's scarce resources, which, in turn, can negatively impact environmental performance $[16,18]$. Accordingly, we posit that the positive effect of green technology adoption on environmental performance may decline after reaching a high level of adoption.

In general, green technology adoption may require major investment in physical assets (e.g., buildings), hardware (computers, machinery, screens, network cables) and software, which have a lengthy amortisation period. Investment in green technology to reduce pollution and carbon emissions also requires the redesign of processes and product development. Following the precepts of the NRBV, Hart and Dowell [59] claim that green technology adoption involves 'developing abilities to deal with areas of knowledge that are uncertain, constantly evolving and dynamically complex'. In this vein, the higher costs of implementing this technology stem not only from the physical provision of the technologies themselves, but also the intense managerial effort required for their strategic installation and exploitation, and integration into management processes and practices [3], which may outweigh the potential savings from their adoption [23-25,65].

The higher the level of adoption of green technology, the greater (1) the employee's knowledge, training and monitoring to ensure the appropriate application of the technology; (2) the technical and managerial integration and coordination between different business functions of the firm, (3) the commitment by the top management team to creating an environmental shared vision in the firm and (4) the continuous outward search for new ideas coming from the firm's surrounding environment and the engagement of its stakeholders [3,7].

Valuable technical knowledge for green technology adoption is often tacit and specialised [66]. If the level of green technology adoption requires the firm to engage in disruptive explorative processes, the gains from green technology may not compensate for the substantial learning process, experimental costs and assets committed to the investment, nor for the consequent strategic changes and structural redesign. A high level of green technology adoption in the firm also requires flexibility in the organisational design to promote the continuous exchange of technical information, policies and environmental aims between different functional areas or groups inside the firm, and cooperation among experts, analysts and decision-makers. Furthermore, both cross-functional coordination and a shared vision are also essential for tackling the potential resistance from employees who have to change their traditional operations and develop new skills to adopt new technologies [66].

Therefore, beyond a certain level of adoption, green technology can become very difficult and costly to manage, thus making the new technology too unwieldy and impractical to translate into environmental outputs, such as reductions of materials, energy and environmental emissions. Moreover, high levels of green technology adoption can draw important resources and managerial capabilities away from core areas of the business, with a resulting lesser impact on new, environmentally-friendly processes and products.

For example, Przychodzen et al. [24], using panel data on 162 companies listed on the Frankfurt Stock Exchange during the period 2007-2016, found that the number of green information technologies introduced by a given firm has permanent negative effects on operating margins and cost management efficiency, although it has a positive long-term impact on profitability and market value. Stucki [23] performed a cross-sectional analysis of firms from Austria, Germany and Switzerland, also finding 
that investment in green technologies may not pay off for firms with low and medium energy costs. Using panel data on German firms' adoption of green technology, Hottenrott et al. [25] showed that, by itself, the adoption of green technologies is associated with lower productivity. The study by Hottenrott et al. [25] indicated the importance of complementing the adoption of green technology with organisational changes to bolster the effects on efficiency and productivity.

Given the above evidence, it seems clear that firms should search for the optimal level of green technology adoption and to equip themselves with the capacities, practices and mechanisms needed to ensure the maximum benefit in terms of (1) better planning and scheduling of the underlying processes and administrative tasks, and (2) monitoring materials and energy consumption patterns [65]. These factors could also explain why there has been limited diffusion of these technologies across the tourism industry to date [7].

In light of the arguments above, we suggest that the adoption of green technologies is beneficial for improving environmental performance, but only up to a point. While the initial effects derived from a firm's capacity to introduce and use green technology can be positive, this may subsequently change once a specific level of green technology adoption is reached. Relying heavily on green technology increases resource waste and coordinating and monitoring costs, and could hamper the development of internal synergies for environmental aims. In short, a moderate level of green technology adoption will be optimal for improving environmental performance. Therefore, we hypothesise the following:

Hypothesis 1 (H1). There is an inverted $U$-shaped relationship between green technology and environmental performance.

\subsubsection{Proactive Environmental Management and Environmental Performance}

The NRBV literature seems to clearly point to the advantages of voluntary self-regulation over coercive regulation, as the former allows firms the necessary flexibility to target and adapt their actions to different environmental conditions [53]. Proactive environmental management creates environmental commitment, in the sense of an organisation-wide recognition of the importance of acting in ways consistent with the interests of the natural environment [30].

EMAS (Eco-Management and Audit Scheme) and ISO 14001 are the two most common examples of voluntary management system certifications aimed at improving firms' environmental performance $[44,52,67,68]$. This type of self-regulation comprises a set of managerial mechanisms, processes and practices related to environmental planning, coordination and control.

Environmental planning involves the establishment of environmental objectives and long-term plans, the allocation of environmental responsibilities, the development of employee training programmes, and the acquisition and implementation of specific technologies and practices [30,68]. Therefore, environmental planning increases environmental awareness, providing new and better directions for decision-making [33]. It also comprises the consistent monitoring of internal operations [53].

Significant cross-functional collaboration and integration is also needed if companies are to incorporate sustainability issues into their operations [43]. Coordination mechanisms provide firms with the flexibility to adapt to different environmental conditions and restrictions in line with their competitive advantage. In this regard, coordination mechanisms increase cost reduction through the prevention of risk and conflicts and the improved management of relations with external stakeholders [69]. These mechanisms also foster communication and transparency, which improve relationships between the organisation and its employees [68,70] and encourages employee learning and innovation [70]. These internal cooperative relationships are essential for the firm to identify and reduce environmental inefficiencies. This is particularly true for tourism firms, given their high water and energy consumption and the excessive use of chemicals, paper and plastics in the service provision [71].

Finally, proactive environmental management includes the adoption of formal techniques and external audits for measuring and assessing environmental performance [48]. Specifically, the ISO 
14001 standard tends to encourage firms to take into account different measurement indicators, such as the use of energy and water, atmospheric emissions and regulatory compliance [30,67]. Hence, the adoption of this voluntary environmental management scheme prompts firms to signal their responsible actions, as called for by more demanding customers. In fact, research on tourism and hospitality firms (e.g., [72]) has shown that one of the main motives managers cite for engaging in proactive environmental management is precisely to enhance the firm's reputation through public recognition of its environmental commitment.

In this regard, the study by López-Gamero et al. [29] of 240 Spanish hotels examines the relationship between environmental management and environmental performance, highlighting their impact in terms of creating specific capabilities for achieving a competitive advantage based on differentiation rather than costs, as expected. The authors also report that firms adopting proactive environmental strategies achieve better economic performance thanks to greater social legitimacy and public approval. The study by Pereira-Moliner et al. [9] of 350 Spanish hotels also confirms the importance of proactive environmental management for both differentiation and cost competitiveness.

The adoption of a proactive environmental management approach also fosters cooperation with key external stakeholders on environmental issues such as waste management or green purchasing [53], or even participation in green supply chains [73]. Cooperation with a wide range of external agents to work on environmental aims is especially critical for the tourism industry, as the competitiveness of its firms is highly dependent on the quality of the natural resources and the welfare of the community living in the tourist destination where they compete [74].

Molina-Azorín et al. [2] and Testa et al. [52] provide a valuable overall review of existing empirical studies on environmental management practices and firm environmental performance. They report that most such studies demonstrate a positive relationship between these two variables, through cost savings $[44,67]$ and technical and organisational innovation $[30,37,52,67]$, contributing to the development higher quality processes and less polluting products [41].

A notable example of an analysis of proactive environmental management systems in the tourism sector is the study by Chan and Wong [75], which provides illustrative cases of the environmental management practices introduced in hotels, mainly linked to ISO 14001 and EMAS adoption, and primarily aimed at reducing energy and costs. Focusing on the Thai hotel industry, Singjai et al. [71] also show that proactive environmental management is associated with positive environmental performance in terms of the consumption of utilities, waste management and environmental risk management.

In addition to identifying a direct effect on environmental performance, the previous literature seems to suggest that proactive environmental management is a necessary platform for fostering complementary environmental practices and technologies $[3,8,22,25,33,48]$. Based on the foregoing, we propose the following hypothesis:

Hypothesis 2 (H2). Proactive environmental management is positively associated with environmental performance.

\subsubsection{Prospector Strategy and Environmental Performance}

Miles and Snow [60] identified three viable strategic positions-prospector, defender, and analyser-that impact firm competitiveness. Firms adopting prospector strategies base their competitiveness on differentiation through the creation of a robust image and market reputation, and on risk-taking and experimentation, stimulating product and service innovation [38,54]. Prospectors are considered pioneers in the market; thus, marketing, R\&D and an external search for emerging opportunities are the main functions in these companies [60]. Defender firms focus on efficiency, concentrating on operations and engineering functions. Under a defender strategy, firms standardise and routinise current procedures and processes, even when the external environment requires changes be made to the firm. Analysers combine features of both prospectors and defenders, defending existing products and markets, reacting to competitors' innovations, and exploring new markets through 
incremental innovations [60]. Finally, firms pursuing a reactor strategy adjust their operations and strategies when there is pressure from the external environment; this is considered an unstable and non-viable organisational form [60].

As postulated by Aragón-Correa [32], the characteristics of a prospector strategy are very similar to those required for achieving a superior environmental performance. Through investments in innovation, $R \& D$ activities and continuous external learning, prospector firms can eliminate environmentally-hazardous product/service production processes, develop new technologies, processes, products and services (with lower life cycle costs) to reduce the environmental impact $[26,30,54,76]$, satisfy new customer needs and exploit new green markets [2,13,43]. In fact, only firms adopting a prospector strategy are considered flexible and innovative enough to address, or even to anticipate, the unique nature of environmental opportunities, constraints and challenges [26], to continuously adapt to consumer preferences and to incorporate them into business processes to achieve environmental innovation [32,70].

Under prospector strategies, firms seek not only radical innovation, but also incremental innovation, that is, they attempt to improve existing processes and products by reducing material inputs-especially polluting and hazardous ones - and energy use [30]. In this vein, and in line with authors such as Passeti and Tenucci [30], we posit that only a prospector strategy can have a clear, direct impact on environmental performance.

Specifically, previous empirical studies such as that of Wagner [77] show that environmental performance has a positive relationship with economic performance when the firm has a proactive pollution control strategy. Using a regression and cluster analysis of 100 Dutch companies, Haverkamp et al. [76] found that firms that adopt more intensive prospector strategies are more likely to adopt environmental actions. Likewise, using panel data of 8922 Spanish firms, Suárez-Perales et al. [38] demonstrated that firms investing in $R \& D$, patenting their innovation and making greater innovation efforts throughout the production cycle achieve better positions in environmental matters.

Compared with the prospector strategy, the defender strategy is rigid, risk-averse and short-sighted, and can turn existing core processes and capabilities into core rigidities when the external environment radically changes [31]. The defender strategy focuses on refining existing processes and products, and on cost control. Therefore, defenders "tend to ignore the changes in the regulatory, cognitive, and normative environment and do not realize that the cost advantages are not sufficient for them to survive or prosper" [31] (p. 415). In fact, Tang and Tang [31], in their empirical research on 115 SMEs in China, found that while the defender strategy was the best fit for the Chinese environment a decade ago, it is currently related only with profitability, and not with the innovative processes and activities needed to improve environmental performance.

In terms of environmental performance, the negative consequences of adopting a cost strategy may be exacerbated in the tourism sector. Decision-makers in tourist firms must anticipate their clients' needs and valuation of the different products and services so that the firm can remain sufficiently differentiated to ensure it is chosen by clients and to prevent its services from becoming commoditised, competing purely on price and transferring all the value to other actors in the sector.

Nor does an analyser strategy yield the necessary innovation and knowledge-creation to directly influence environmental performance [26,30,54], as it has a limited proactive focus. Therefore, we argue that a prospector strategy is the only type that can give the firm a direct competitive advantage in environmental performance terms. On the basis of the above insights, we formulate the following hypothesis:

Hypothesis 3 (H3). A prospector strategy is positively associated with environmental performance.

\subsection{Moderating Effects}

\subsubsection{Proactive Environmental Management}

Previous studies (e.g., $[9,41,53])$ suggest that proactive environmental management-through the adoption of EMAS or ISO 14001 regulations, for instance- - helps the firm to identify and acquire specific green technologies, and shortens the time required to introduce them [33]. Proactive environmental 
management becomes a clear function in a firm's hierarchy, which generates positive impacts on other organisational areas and fosters the leadership and motivation needed to encourage the adoption of these technologies by the organisation's employees [78].

The implementation of a formal environmental planning, management and control system can also create synergies in the management and exploitation of green technologies to improve environmental performance [3,7,9]; indeed, better-managed firms tend to have lower energy intensity [79].

First of all, the alignment of goals and resources, and enhanced communication between all the different organisational levels, can improve the firm's efficiency and effectiveness in implementing green technologies $[3,33]$, thereby reducing subprocesses, defects (in both processes and final products), material losses and waste, and downtime.

Cross-functional communication and exchange of information also ensures the efficacy and efficiency of the adoption of green technology, as it helps everyone in the firm understand the goals of the implementation and the benefits the new environmental technology will bring to the organisation as a whole and to specific functions. Moreover, such communication is essential for conveying the instructions for its successful and productive usage. This coordination among business units and their resource allocations thus allows the firm to reshape its institutionalised processes and to explore efficient new alternatives [80] for the application of green technology.

Furthermore, the cross-functional or inter-departmental adoption of green technology underpinned by proactive environmental management can create an idiosyncratic, socially-complex bundle of resources and capabilities, deeply embedded in routines, which can generate sustainable competitive advantage [81].

Secondly, the availability of joint training helps ensure that the firm's employees are up-to-date with, and motivated by, the new technologies and measures being implemented. Chan et al. [7] highlight employees' environmental attitudes as a crucial factor for successful green technology implementation in hotels, as the changes to habitual operations that the adoption of this technology involves may generate resistance from the firm's employees.

Thirdly, the continuous improvement incorporated into proactive environmental management [53] also increases the potential of the application of green technology to reduce emissions and waste [82], as firms base their approach on well-defined environmental objectives, rather than on expensive end-of-pipe capital investment to control emissions.

In addition, the adoption of voluntary management system certifications helps showcase the firm's beneficial actions, drawing attention to its willingness to act responsibly. Such certifications can also help to establish relationships of trust with customers, other firms and suppliers [48], which can provide new external technical and/or practical know-how on how to better apply and maintain green technology $[7,32,44]$, and may even enable the firm to identify the optimal level of adoption at the lowest possible cost.

Specifically, supplier involvement enables the firm to obtain high-quality components and raw materials with minimal environmental hazard, which helps to enhance the impact of green technology in terms of producing products and services that are less energy-, material- and time-intensive [59,81]. For example, although green technologies have great potential to reduce $\mathrm{CO} 2$ emissions, the best outcome is actually achieved by the selection of appropriate clean energy, fuels and equipment (e.g., fridges, toilets, composters, bulbs, sensors, pipelines, cabling, glazing, etc.), and using lighter materials, such as plastic, aluminium and magnesium. In the tourism sector, there is a growing need to cooperate with suppliers on the development of green technologies to work with low-carbon sustainable fuels, thereby driving energy and resource efficiency [11].

For their part, suppliers of green technology can provide continuous support and training to employees during the implementation of the new technology [83]. They can even assist the firm in developing an integrative infrastructure that fosters communication among the firm's different areas (and their specific technologies), and consequently bolster the level of green technology adoption in the company as a whole. 
A strong relationship with suppliers can even reduce the high maintenance costs and help establish the necessary in-house maintenance in the early stages of green technology adoption (7).

In this sense, and considering the complexity of firms that supply and assist with green technologies [84], the acquiring firm's establishment of formal procedures to manage environmental issues can foster the internal generation of technical expert knowledge related to the strategic application of green technology. An explanation for these ideas can be found in the theory of absorptive capacity [85], according to which prior related practices are necessary to acquire specialised external knowledge and resources, such as that from suppliers in the industrial equipment sector.

Cooperation among tourism firms is also crucial for the diffusion of green technology in the sector. In this vein, the research by Zhou et al. [11] highlights the importance of the hospitality industry cooperating with the transport industry to accelerate the decarbonisation of tourist transport through the use of cleaner fuels (e.g., biofuels, fuel cells) and more efficient vehicles.

Although there is still very little empirical literature in this area, existing studies seem to clearly indicate that the development of proactive environmental management can enable the acquisition and integration of green technology in the firm's environmental management processes in order to improve environmental performance $[3,25,33]$.

Specifically, using data from a sample of 151 Chinese firms, Wang et al. [3] show that the firms' capacity to integrate IT into their environmental management processes-by leveraging IT infrastructure flexibility, IT personnel skills and IT-business alignment-improves environmental performance. Hottenrott et al. [25] also find, using a panel data of German firms, that whereas the sole adoption of new green technology is associated with lower productivity, its integration with innovative organisational management structures and practices is not. Moreover, the study by Ozusaglam et al. [33], based on 36,645 firms from eight countries, shows that the development of proactive environmental management could reduce the cost and time required for technology implementation, thus increasing the efficiency of internal processes.

In light of the above, we hypothesise that proactive environmental management helps leverage green technology infrastructure to improve environmental performance. In this sense, for the same level of green technology adoption, firms employing proactive environmental management can achieve better environmental outcomes. Given the curvilinear relationship, firms with greater adoption of proactive environmental management show a higher point of maximum efficiency (in terms of the use of green technology to improve environmental performance) than firms with lower levels of proactive environmental management. We can thus formulate the following hypothesis:

Hypothesis 4 (H4). The inverted U-shaped relationship between green technology and environmental performance is positively moderated by proactive environmental management, in such a way that greater proactive environmental management is associated with a higher point of maximum efficiency on the inverted U-shaped curve.

\subsubsection{Prospector Strategy}

Considering the substantial demands of capital, time and expertise required to implement green technologies, top managers' environmental attitudes and strategic perspectives on the perceived benefits of these technologies would seem to be crucial [9,22,78]. In addition, Vickers [86] points out that green technology adoption should be receptive to a broader-than-usual set of knowledge from diverse sources. According to Sharma and Vredenburg [87], prospector firms are the most responsive to environmental challenges, increasing shareholder value through higher-order learning, continuous technological innovation and stakeholder integration.

Prospector firms, with their outward-looking approach, are characterised by their intensive search for new, environmentally-protective technologies $[26,88]$. This creates an optimal environment for the firm to create or identify, assimilate and use new knowledge to enhance the application of new or 
existing technologies [80], to find efficient new ways to produce, package and market goods and services to environmentally-concerned customers, and to address evolving environmental problems [82].

Employee's learning and experience could thus be associated with greater time compression efficiency in green technology implementation [89]. Therefore, prospector firms strengthen the positive linkage between green technologies and environmental performance by generating competitively-valuable tacit knowledge and skills [87].

Specifically, Christmann [88] provides evidence showing that the higher the firm's levels of green technology innovation, the greater the cost advantage it will obtain from proactive environmental strategies. Prospector strategies can anticipate future environmental regulation, which minimises the disruptions to the production process associated with developing and implementing compliance technologies, and achieves learning curve effects in the implementation process [88].

Prospector strategies also seek to foster the product stewardship capability emphasised in the NRBV $[26,59]$ through the involvement of both internal and external stakeholders in business decisions to enhance internal processes and outcomes $[30,54,88]$. Specifically, the integration of green customer preferences [13] can provide a clear orientation for the successful application of green technology to the provision of new services and products with minimal environmental impact and lower life-cycle costs $[2,88]$. Market focus can also help the firm to gain a better understanding of the optimal level of adoption of a certain green technology, according to the reactions of the consumers to the resulting outcomes.

Extending the precepts of the NRBV, Sharma and Vredenburg [87] find that effective stakeholder integration enables organisations to better manage their green programmes and technologies, focusing not only on achieving reductions in energy and material consumption, but also on pollution prevention. In this vein, prospector firms seek to ensure that their use of green technology follows a pollution prevention approach rather than applying "end-of-pipe" pollution control techniques [90]. In accordance to the precepts of the NRBV, the former is associated with reduced lower costs and higher efficiency, due to the reduction in the inputs required, the simplification of the processes and reduction of non-quality costs [59].

Furthermore, this strategy also strengthens the relationship with other key external stakeholders, such as suppliers, competitors, institutions, trade associations and the local community, which is an important factor in tourism sector competitiveness [2,30]. Such relationships could also foster the absorption of new ideas [85] to prompt the strategic exploitation of green technology [68] and compensate for the lack of knowledgeable specialist staff in most tourism firms [88].

All in all, despite the lack of empirical studies specifically addressing this topic, the literature seems to agree that the adoption of prospector strategies is necessary to increase and sustain the impact of green technology on environmental performance [26,47] by giving such technologies the strategic direction needed to adapt to continuously-evolving environmental challenges.

Considering the curvilinear relationship between green technology and environmental performance, we posit that prospector firms will show a higher point of maximum efficiency in comparison to those adopting a reactor strategy for a certain level of green technology implementation. Therefore, we propose the following hypothesis:

Hypothesis 5 (H5). The inverted U-shaped relationship between green technology and environmental performance is positively moderated by the adoption of a prospector strategy in such a way that a prospector strategy is associated with a higher point of maximum efficiency on the inverted $U$-shaped curve.

\subsubsection{Defender Strategy}

As posited above, defender strategies can help a firm to achieve greater organisational efficiency $[7,31]$. However, according to the precepts of the NRBV, the adoption and implementation of green technology entails an innovation focus based on continuous experimentation, rather than a cost 
reduction orientation $[31,88]$. The complex nature of green technologies also requires firms developing or adopting them to make major investments of capital, time and resources $[7,30]$, and to employ specific green capabilities [39].

That is, by its nature, the defender strategy runs counter to [31,76] risk-taking and the accumulation of the resources and capabilities required to acquire, manage and strategically apply green technologies to prevent environmental degradation [1,39]. Indeed, Chan et al. [7] highlight the cost-orientation and short-sighted perspective associated with the defender strategy as the main barriers to the introduction and diffusion of green technology in the tourism sector.

Therefore, given the curvilinear relationship between green technology and environmental performance, we posit that defender firms will show a lower point of maximum efficiency than the reactor strategy. Accordingly, the following hypothesis is proposed:

Hypothesis 6 (H6). The inverted U-shaped relationship between green technology and environmental performance is negatively moderated by the adoption of a defender strategy in such a way that a defender strategy is associated with a lower point of maximum efficiency on the inverted $U$-shaped curve.

\subsubsection{Analyser Strategy}

As mentioned above in the justification for hypothesis 3, when applied in isolation, analyser strategies are understood to have a limited ability to generate an environmental performance advantage in the current competitive context $[1,30,31]$ due to their reactive strategic focus.

Nevertheless, this hybrid form of defender and prospector strategies could ensure efficiency in green technology adoption while also encouraging better use of these technologies through incremental innovation, taking advantage of the emerging opportunities raised by pioneer competitors in the field.

Analyser firms opt for the acquisition or the internal development of technology once its feasibility has been demonstrated in the market [60]. This approach minimises uncertainty in the management and final application of new technology to processes and products, as well as the associated costs. Analyser firms thus promote the acquisition of new practices and knowledge which are related to the firm's existing knowledge base, technology paths and markets [60].

The efficiency of this hybrid form of defender and prospector strategies can be seen not only in analyser firms' acquisition of different knowledge, practices and technologies, but also in the application to existing processes and products, or new ones whose viability has also been largely proven in the market; in other words, such firms specialise in incremental innovation [31,60]. In this sense, we expect analysers to take fewer risks and make fewer mistakes when applying green technology, given their goal of maintaining stable operations while being quick followers. Although analysers are expected to be less innovative than prospectors in terms of the adoption of green technology for environmental performance, they may achieve greater operational efficiency in the application of green technology.

However, besides postulating a relationship between the adoption of an analyser strategy and green technology, we argue-drawing on the complementary assets approach [91] and the orchestration of resources related to the dynamic capabilities theory $[27,28]$ - that their joint deployment can generate more intangible assets that enable the firm to achieve critical environmental competitive advantages $[26,29]$. Therefore, strategies that are less proactive can still be associated with superior environmental performance, 'if the prerequisite strategic organisational resources have been developed as a part of other management initiatives' [90].

Considering the curvilinear relationship between green technology and environmental performance, we posit that analyser firms will show a higher point of maximum efficiency in comparison to reactors. In light of the above, we hypothesise that: 
Hypothesis 7 (H7). The inverted $U$-shaped relationship between green technology and environmental performance is positively moderated by the adoption of an analyser strategy, in such a way that an analyser strategy is associated with a higher point of maximum efficiency on the inverted U-shaped curve.

\section{Materials and Methods}

\subsection{Data}

The database we use consists of 1019 firms operating in the Spanish tourism industry, with a confidence level of $95 \%$ and a margin of error of $\pm 3.1 \%$. This final sample represents a response rate of $25.6 \%$ from the initial sample of 8148 firms, selected from the entire population of Spanish tourism companies listed in the 2008 Central Companies Directory (DIRCE). This initial sample was selected using a stratified random sampling procedure with proportional allocation to ensure the representativeness of the sample in terms of activity (four groups), size (taking the number of employees as a measure of firm size) and location.

The initial data used to create the database were obtained from a questionnaire conducted in 2009 through personal interviews with the CEO or general manager. We applied a modified version of Dillman's Total Design Method [92] to mitigate the problems associated with questionnaires as a data collection method, and to improve the response rate and the quality of the information. These practices include using a questionnaire validated by pilot tests, identifying a coordinator in the firm who manages the information and has the necessary knowledge to provide valid responses, including a report with the questionnaire setting out the project's aims and its expected contributions, and providing a contact telephone number and e-mail address to answer any questions about the survey. Prior to administering the final questionnaire, it was pre-tested on a group of five academics specializing in the fields of tourism and strategy. This pre-test was carried out in the first two weeks of November 2009. The resulting questionnaire was then also administered to eight managers from firms of different sizes and activities in the tourism sector. The managers' comments and suggestions for improvement were taken into account in the final questionnaire design.

The interviews were conducted by a company specializing in tourism market research, in close collaboration with the research team responsible for the project. The fieldwork team was made up of 18 people with experience in survey-based interviewing and medium-to-high level academic qualifications that facilitated their understanding and the administration of the questionnaire. The questionnaire was sent to the managers in advance to ensure they had time to read it and consider their responses. Appointments were then made by telephone or e-mail. Firms that initially declined to participate in the study were substituted by others with the same socio-demographic characteristics (by activity, location and size stratum). The average length of each interview was one hour; this field work was carried out from December 2009 to March 2010. The firms included in the final sample, although heterogeneous, were differentiated by their size, their endowment of resources and capabilities, their management styles and strategy types. These factors were considered appropriate for capturing the differences among their business models.

We also added data from the Sistema de Análisis de Balances Ibéricos (SABI), a database managed by Bureau Van Dijk and Informa D\&B, S.A., to complete the financial information from 2008 to 2016. The final database used in this study contained 446 Spanish tourism firms: 121 hotels, 204 restaurants, 29 travel agencies and tour operators, 20 transport companies and 72 firms providing products/services considered complementary to tourism.

\subsection{Variables}

In this section, we provide an overview of the measurements of the dependent and independent variables used in our baseline model on environmental performance and its determinants in tourism firms. The dependent variable and some of the independent ones were measured by seven-point 
Likert-type self-evaluation scales. For each item, respondents were asked to compare the position and strength of their firm to that of other competitors in their specific subsector.

In order to address the potential problem of autocorrelation, we placed questions relating to dependent variables after those for independent variables in the questionnaire to reduce the impact of respondents' implicit effectiveness theories [93]. Moreover, since some of the constructs considered were measured using items in a questionnaire completed by a single respondent, we also conducted Harman's one-factor test [93] to check whether common method variance was a serious issue.

In this test, all items are entered together into a factor analysis, and the results of the unrotated factor solution are examined. If substantial common method variance was present, either a single factor would emerge, or one general factor would account for most of the covariance in the independent and criterion variables $[93,94]$. When all the items were entered into a principal components factor analysis, no general factor emerged from the unrotated factor solution. That is, multiple factors were detected and the variance did not stem solely from the first factors [93]. Moreover, this study verified the convergent validity of the subjective measures from self-evaluation using objective measures which were both internal and exogenous to the firm [94] (details below).

We also included control variables that have a bivariate correlation below 0.3 [94] between the other variables in the model. The statistical tests do not entirely rule out the possibility of common method variance; however, they suggest that our results are not predominantly driven by it. Moreover, our results are based on complex estimations that involve multiple independent variables and interactions terms. It has been argued that it is highly unlikely that the results of such models emerge solely as a result of common method biases [95].

\subsubsection{Dependent Variable}

\section{Environmental Performance (ENVPERF)}

This variable was measured with a seven-point Likert-type scale reflecting managers' perceptions of the firm's level of achievement of environmental objectives $(1=$ "very low", $2=$ "low", $3=$ "quite low", $4=$ "average", $5=$ "quite high", $6=$ "high", and 7 = "very high") as compared to competitors in their specific subsector. Specifically, it includes five items adapted from previous studies [96] also validated in recent literature (e.g., $[37,71,73])$, i.e., 'Reduction in the consumption of materials for service provision', 'Reduction in the energy consumption for service provision', 'Reduction in the time required for service provision', 'Reduction in the environmental impact', and 'Improvement of equipment efficiency'.

\subsubsection{Independent Variables}

\section{Green Technology (GREENT)}

There is no established scale in the literature to measure green technology [33]. As such, this research proposes a seven-point Likert-type scale reflecting managers' perception of the degree of implementation $(1=$ "very low", $2=$ "low", $3=$ "quite low", $4=$ "average", $5=$ "quite high", $6=$ "high", and 7 = "very high") of technologies that ensure the reduction of materials, energy and emissions, and prevent pollution $[25,48]$, as compared to competitors in their specific subsector. Specifically, the three items included are 'Energy-saving technologies', 'Development of sustainable buildings' and 'Industrial automation (intelligent conservation chambers, kitchens with efficient energy control, etc.)', which are in line with the most common green technologies adopted in the tourism sector (e.g., [2,7]).

\section{Proactive Environmental Management (ENPROMA)}

Following previous studies (e.g., [2,52]), managerial commitment to sustainability issues has been measured through the number of quality certificates that the firm holds, such as EMAS, ISO 14001 or other environmental certifications involving the adoption of voluntary environmental and 
energy management systems. The aggregated sum of these three certificate types was weighted by the firm's commitment to developing a total quality management system $(1=$ no commitment, $2=$ low commitment, 3 = average, $4=$ high commitment, and $5=$ very high commitment), given their relationship with environmental management practices (e.g., [8]).

\section{Business Strategies}

To capture the effect of the firm's strategic positioning, the analysis includes three dichotomous variables that reflect the prospector (PROSPEC), defender (DEFEND) or analyser (ANALY) nature of the firm's organisational strategy; the reference variable is the absence of a clearly-defined organisational strategy, that is, the reactor strategy. The paragraph approach proposed by Snow \& Hrebiniak [97] was used to categorise firms into strategic archetypes, following Miles \& Snow's strategic typology.

\subsubsection{Control Variables}

Different factors that could have an effect on environmental performance are also included in the model as control variables. Size (SIZE) influences a firm's ability to achieve economies of scale related to innovation, and is thus commonly considered a predictor of environmental performance [98]. Large firms can also invest more in technology and systems to prevent environmental damage [72]. Size is measured as the total number of employees.

Age (AGE) can affect the development of more proactive environmental management and public visibility [3] by leveraging the accumulated experience. It is measured as the number of years since the opening of the first establishment.

Another important size-related variable to consider in the tourism sector is chain affiliation (CHAIN) [7]. Specifically, Bohadanowicz [99] and Pereira-Moliner et al. [9] demonstrate that chain-affiliated hotels are more likely to pay attention to environmental issues than independent ones. CHAIN is a dichotomous variable that takes a value of 1 if the firm is part of a chain and 0 otherwise.

We also include non-quality costs $[100,101]$ (NQUACOST) as the percentage of services provided that were considered unacceptable by customers, given its expected negative impact on environmental performance.

Finally, since the sample includes different subsectors of tourist firms, which presumably have different patterns of environmental performance, four dummy variables are introduced: accommodation firms (HOTEL), restaurants (RESTA), travel agencies and tour operators (TOUR), and transport organisations (TRANSP), taking complementary firms as the reference subsector.

Table 1 presents the descriptive statistics and the correlations of the study variables. As a measure of scale reliability, Cronbach's alpha coefficient exceeded the generally-accepted minimum of 0.7 for environmental performance (0.897) and green technology scales (0.697) [102]. The levels of correlation between the variables are low, below 0.6 (see Table 1) [103], confirming the discriminant validity of the model. The convergent validity of the dependent variable was also verified with objective internal (concurrent validity) and external (predictive validity) measures of the firm. Specifically, concurrent validity was tested by verifying whether the measure of environmental performance based on the manager's perceptions was convergent with the objective measure of internal R\&D expenses (developed with firm's internal employees). The Pearson correlation coefficient between the two variables was positive $(r=0.107)$ and statistically significant $(p<0.05)$. Predictive validity was verified by means of the correlation between environmental performance and economic performance; these are both considered dimensions of sustainability [13]. Performance was operationalised with the ROA indicator taken from the annual accounts for 2010 compiled in the SABI database. The results revealed positive correlations $(p<0.01)$ between environmental performance and economic performance $(r=0.136)$. 
Table 1. Descriptive statistics and correlations of the study variables.

\begin{tabular}{|c|c|c|c|c|c|c|c|c|c|c|c|c|c|c|c|c|}
\hline VARIABLES & $\mu$ & $\sigma^{2}$ & 1 & 2 & 3 & 4 & 5 & 6 & 7 & 8 & 9 & 10 & 11 & 12 & 13 & 14 \\
\hline 1.SIZE & 14.735 & 43.085 & 1 & - & - & - & - & - & - & - & - & - & - & - & - & - \\
\hline 2.AGE & 28.099 & 23.274 & $0.126^{* * *}$ & 1 & - & - & - & - & - & - & - & - & - & - & - & - \\
\hline 3.CHAIN & 0.0919 & 0.289 & $0.275^{* * *}$ & $0.101 * *$ & 1 & - & - & - & - & - & - & - & - & - & - & - \\
\hline 4.NQUACOST & 3.674 & 6.870 & -0.015 & 0.005 & -0.013 & 1 & - & - & - & - & - & - & - & - & - & - \\
\hline 5.HOTEL & 0.271 & 0.445 & $0.265^{* * * *}$ & $0.119^{* * * *}$ & $0.207^{* * *}$ & 0.004 & 1 & - & - & - & - & - & - & - & - & - \\
\hline 6.RESTA & 0.457 & 0.499 & $-0.191^{* * *}$ & -0.006 & $-0.183^{* * *}$ & 0.027 & $-0.560^{* * *}$ & 1 & - & - & - & - & - & - & - & - \\
\hline 7.TOUR & 0.065 & 0.247 & -0.043 & $-0.066^{*}$ & $0.073 *$ & $-0.074^{*}$ & $-0.161^{* * *}$ & $-0.242^{* * *}$ & 1 & - & - & - & - & - & - & - \\
\hline 8.TRANSP & 0.045 & 0.207 & 0.009 & 0.008 & -0.031 & -0.034 & $-0.132 * * *$ & $-0.199 * * *$ & -0.057 & 1 & - & - & - & - & - & - \\
\hline 9.GREENT & 1.522 & 1.101 & $0.262 * * *$ & $0.178^{* * *}$ & $0.110^{* * *}$ & -0.055 & $0.386^{* * *}$ & $-0.241^{* * *}$ & -0.045 & -0.027 & 1 & - & - & - & - & - \\
\hline 10.ENPROMA & 0.267 & 1.211 & $0.204^{* * *}$ & $0.136^{* * *}$ & $0.175^{* * *}$ & 0.063 & $0.206^{* * *}$ & $-0.110^{* * *}$ & $-0.077^{*}$ & 0.008 & $0.319^{* * *}$ & 1 & - & - & - & - \\
\hline 11.PROSP & 0.381 & 0.486 & -0.017 & -0.004 & 0.025 & 0.051 & -0.006 & 0.021 & $0.110^{* * *}$ & 0.022 & $0.149^{* * *}$ & 0.052 & 1 & - & - & - \\
\hline 12.DEFEND & 0.07 & 0.255 & 0.039 & 0.002 & -0.010 & 0.002 & -0.032 & 0.049 & -0.057 & -0.014 & $-0.089^{* *}$ & -0.041 & $-0.578^{* * *}$ & 1 & - & - \\
\hline 13.ANALY & 0.352 & 0.478 & $0.081^{* *}$ & 0.060 & $0.096^{* *}$ & -0.019 & $0.131^{* * *}$ & $-0.127^{* * *}$ & 0.035 & 0.026 & $0.175^{* * *}$ & $0.235^{* * *}$ & $-0.201 * * *$ & $-0.214^{* * *}$ & 1 & - \\
\hline 14.ENVPERF & 3.370 & 1.561 & $0.108^{* *}$ & $0.094^{* *}$ & $0.140^{* * *}$ & -0.029 & $0.126^{* * *}$ & $-0.141^{* * *}$ & $0.161^{* * *}$ & $0.104^{* *}$ & $0.321^{* * *}$ & $0.236^{* * *}$ & $0.196^{* * *}$ & $-0.120^{* * *}$ & $0.098^{* *}$ & 1 \\
\hline
\end{tabular}

${ }^{* * *}$ Correlation significant at the 0.01 level (bilateral); ${ }^{* *}$ Correlation significant at the 0.05 level (bilateral); ${ }^{*}$ Correlation significant at the 0.1 level (bilateral). 


\subsection{Method of Analysis}

Hierarchical regression analysis is carried out to test the aforementioned hypotheses using SPSS 25.0. Before entering the moderating effects, the main variables are mean centred to reduce multicollinearity $[104,105]$. Analysis of the variance inflation factors shows that multicollinearity is not a problem: the highest factor is 9.091 , i.e., below the cut-off level of 10 [104]. The results are statistically robust, as compliance with the basic assumptions for regression analysis was verified by an analysis of the residuals and of other graphs and statistics provided by the program.

\section{Findings and Results}

Table 2 displays the results of estimating the model for each of the proposed relationships. The significance of the F statistic is acceptable for all the estimated models. As can be seen, the explanatory power of the models increases first when the explanatory variables are introduced, and then when the moderating effects are introduced. In the case of the complete model with the direct and moderating effects, adjusted $\mathrm{R}^{2}$ shows an explanatory power for environmental performance of $20.5 \%$.

Table 2. Estimation results.

\begin{tabular}{|c|c|c|c|c|c|c|c|}
\hline & & \multicolumn{2}{|c|}{ Model I } & \multicolumn{2}{|c|}{ Model II } & \multicolumn{2}{|c|}{ Model III } \\
\hline & & (1) & (2) & (1) & (2) & (1) & (2) \\
\hline & Constant & $2.764^{* * *(3)}$ & 6.394 & $3.173^{* * *(3)}$ & 7.478 & $3.102 * * *(3)$ & 7.963 \\
\hline \multicolumn{8}{|c|}{ Control variables } \\
\hline 1 & Size & 0.049 & 0.997 & -0.015 & -0.316 & -0.019 & -0.408 \\
\hline 2 & Age & 0.072 & 1.548 & 0.034 & 0.769 & 0.025 & 0.559 \\
\hline 3 & Chain affiliation & $0.083 *$ & 1.711 & 0.064 & 1.396 & 0.074 & 1.618 \\
\hline 4 & Non-quality costs & -0.009 & -0.187 & -0.017 & -0.397 & -0.025 & -0.578 \\
\hline 5 & Hotels & $0.180^{* * *}$ & 2.755 & 0.066 & 1.044 & 0.081 & 1.285 \\
\hline 6 & Restaurants & 0.068 & 1.027 & 0.062 & 0.993 & 0.067 & 1.078 \\
\hline 7 & $\begin{array}{c}\text { Travel agencies and tour } \\
\text { operators }\end{array}$ & $0.216^{* * *}$ & 4.099 & $0.196^{* * *}$ & 3.905 & $0.195^{* * *}$ & 3.935 \\
\hline 8 & Transport & $0.155^{* * *}$ & 3.067 & $0.142^{* * *}$ & 2.976 & $0.142 * * *$ & 3.017 \\
\hline \multicolumn{8}{|c|}{ Explanatory variables } \\
\hline 9 & Green Technology & - & - & $0.444^{* * *}$ & 4.872 & $0.345^{* * *}$ & 3.510 \\
\hline 10 & Green Technology ${ }^{2}$ & - & - & $-0.226^{* * *}$ & -2.690 & $-0.277^{* * *}$ & -3.256 \\
\hline 11 & $\begin{array}{c}\text { Proactive Environmental } \\
\text { Management }\end{array}$ & - & - & $0.129^{* * *}$ & 2.724 & $0.145^{* * *}$ & 2.931 \\
\hline 12 & Prospector & - & - & $0.122 * *$ & 2.004 & $0.281^{* * *}$ & 3.754 \\
\hline 13 & Defender & - & - & 0.004 & 0.063 & $0.170 * *$ & 2.257 \\
\hline 14 & Analyser & - & - & 0.015 & 0.290 & 0.067 & 1.130 \\
\hline \multicolumn{8}{|c|}{ Moderating effects } \\
\hline 15 & $\begin{array}{c}\text { Green Tech } \times \\
\text { Environmental Proactive } \\
\text { Management }\end{array}$ & - & - & - & - & $-0.091^{* *}$ & -1.731 \\
\hline 16 & Green Tech $\times$ Prospector & - & - & - & - & $0.440^{* * *}$ & 3451 \\
\hline 17 & Green Tech $\times$ Defender & - & - & - & - & $0.410 * * *$ & 3422 \\
\hline \multirow[t]{5}{*}{18} & Green Tech $\times$ Analyser & - & - & - & - & $0.355^{* * *}$ & 3716 \\
\hline & $\mathrm{F}$ & $5.269 * * *$ & & $8.209^{* * *}$ & - & $7.394^{* * *}$ & - \\
\hline & $R^{2}$ & 0.088 & & 0.211 & - & 0.238 & - \\
\hline & Adjusted $R^{2}$ & 0.071 & & 0.185 & - & 0.205 & - \\
\hline & Changes in $R^{2}$ & - & - & $0.123^{* * *}$ & - & $0.027^{* * *}$ & - \\
\hline
\end{tabular}

(1) Standardised regression coefficients; (2) $t$-values; (3) Non-Standardised Beta; ${ }^{*} p<0.1{ }^{* *} p<0.05$; ${ }^{* * *} p<0.01$. 
Model 1 shows the relationships between the control variables and environmental performance. The analysis of the control variables reveals that chain affiliation $(0.083, p<0.1)$ has a significant positive effect on environmental performance. On the other hand, size, age and non-quality costs have no significant effects on environmental performance $(0.049, p>0.1 ; 0.072, p>0.1 ;-0.009, p>0.1$, respectively). As for the subsector variables, only hotels $(0.180, p<0.01)$, tour operators and travel agencies $(0.216, p<0.01)$, and transport companies $(0.155, p<0.01)$ report positive significant effects on environmental performance, in comparison to the complementary offer subsector.

Model 2 incorporates the direct effects of the explanatory variables on green technology, and its quadratic term, proactive environmental management and prospector strategy. The green technology variable has a positive and significant coefficient $(0.444, p<0.01)$, while the quadratic term has a negative and significant coefficient $(-0.226, p<0.01)$. Taken together, these two effects suggest that green technology has a curvilinear effect on environmental performance.

For ease of interpretation, these effects are shown graphically. Figure 2 depicts an inverted $\mathrm{U}$-shaped line that captures the relationship between the level of green technology adoption and environmental performance. It implies that firms that adopt green technology enjoy greater benefits in terms of efficiency in the use of materials and resource waste and the impact on the environment. Yet, they do so only up to a point (a threshold of 4.5 , equivalent to a $64 \%$ degree of adoption). Beyond this threshold, higher levels of adoption or use of green technologies in firms is associated with an incremental reduction in their environmental performance. This finding supports hypothesis 1.

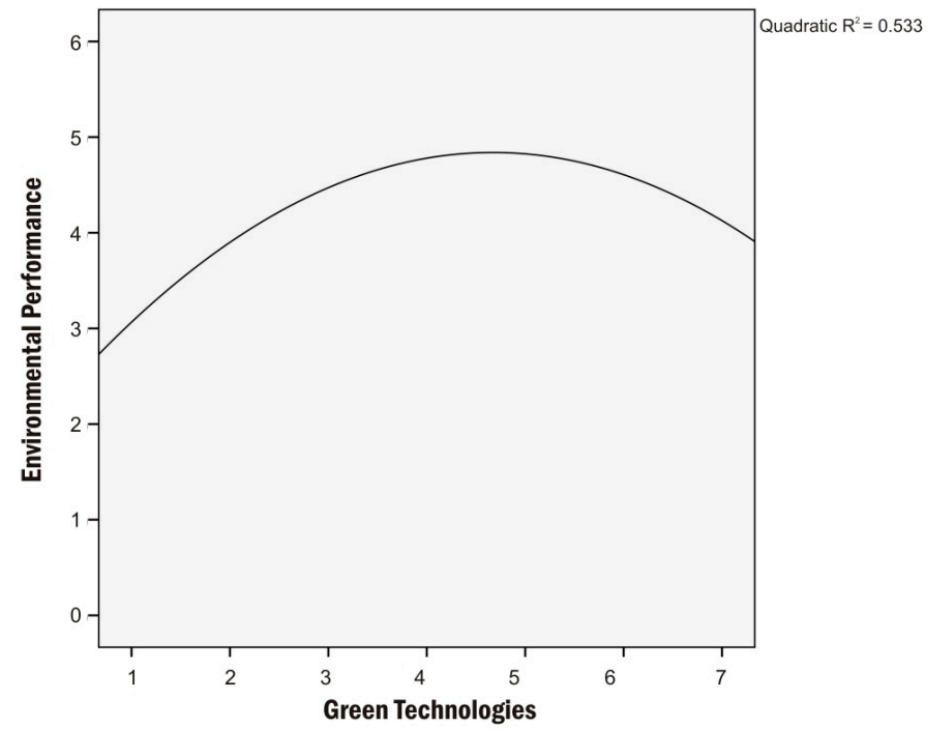

Figure 2. Direct effect of green technology on environmental performance.

Proactive environmental management also positively impacts environmental performance $(0.129$, $p<0.01)$. As for the strategic positioning, only firms adopting a prospector strategy show a positive effect on environmental performance $(0.122, p<0.05)$. In contrast, neither analyser nor defender strategies seem to have a direct impact on environmental performance, as expected. Therefore, $\mathrm{H} 2$ and $\mathrm{H} 3$ are also empirically supported.

Model 3 includes the interactions terms. It considers the moderating effect on the relationship between green technology and environmental performance exerted by proactive environmental management and business strategies.

Although it is a small effect, proactive environmental management shows an unexpected negative significant impact on the relationship between green technology and environmental performance $(-0.091, p<0.1)$. The adoption of a prospector strategy has a positive and significant moderating effect on the relationship between green technology and environmental performance $(0.440, p<0.01)$ in comparison to the reactor strategy. Defender and analyser firms also exert positive moderating effects 
on the relationship between green technology and environmental performance $(0.410, p<0.01 ; 0.355$, $p<0.01$, respectively) in comparison to the reactor strategy.

However, it is not immediately apparent from the model how these conditional effects influence the relationship between green technology and environmental performance. As suggested by Aiken et al. [104], one approach is to graph the main effects given the conditional effect under study.

Figure 3 shows that green technology is associated with higher environmental performance when an explicit proactive environmental management action is taken (the adoption of at least one certification scheme, such as ISO, EMAS or environmental certificates). Managers that demonstrate a proactive environmental commitment can achieve high levels of efficiency in the use of green technologies for improved environmental performance, up to a relatively high level of green technology adoption (a threshold of 5.5, equivalent to a $78.6 \%$ degree of adoption), at which point the degree of implementation of these technologies is so high that proactive environmental commitment and practices have no moderating effect. As the adoption of green technology rises above this threshold, the two curves tend to converge. This convergence may confirm that a very high degree of green technology adoption is detrimental to environmental performance, regardless of the proactive management of the firm. Furthermore, more proactive environmental management is also associated with increasing levels of environmental performance up to a medium-high level of green technology adoption (a threshold of 4.5 , equivalent to a $64 \%$ degree of adoption). Thus, these results partially support hypothesis 4 .

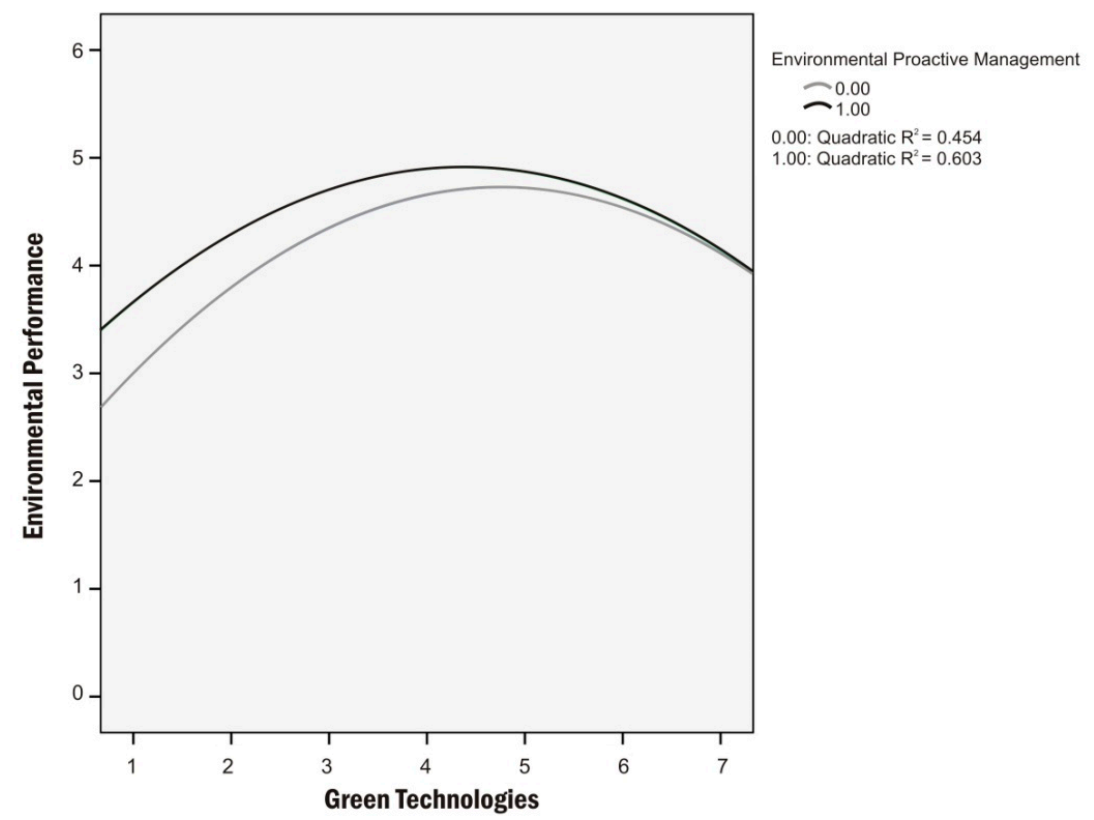

Figure 3. Moderating effect of proactive environmental management on the relationship between green technology and environmental performance.

As shown in Figure 4, firms adopting a prospector strategy reach maximum levels of efficiency in the implementation of green technologies to improve environmental performance, as predicted in H5. Regardless of the level of implementation of green technologies, adopting a prospector strategy will always leverage the impact of green technology on environmental performance. However, it is worth noting that the difference between prospector and reactor strategy firms in terms of the impact of green technology on environmental performance becomes smaller with high levels of green technology adoption. 


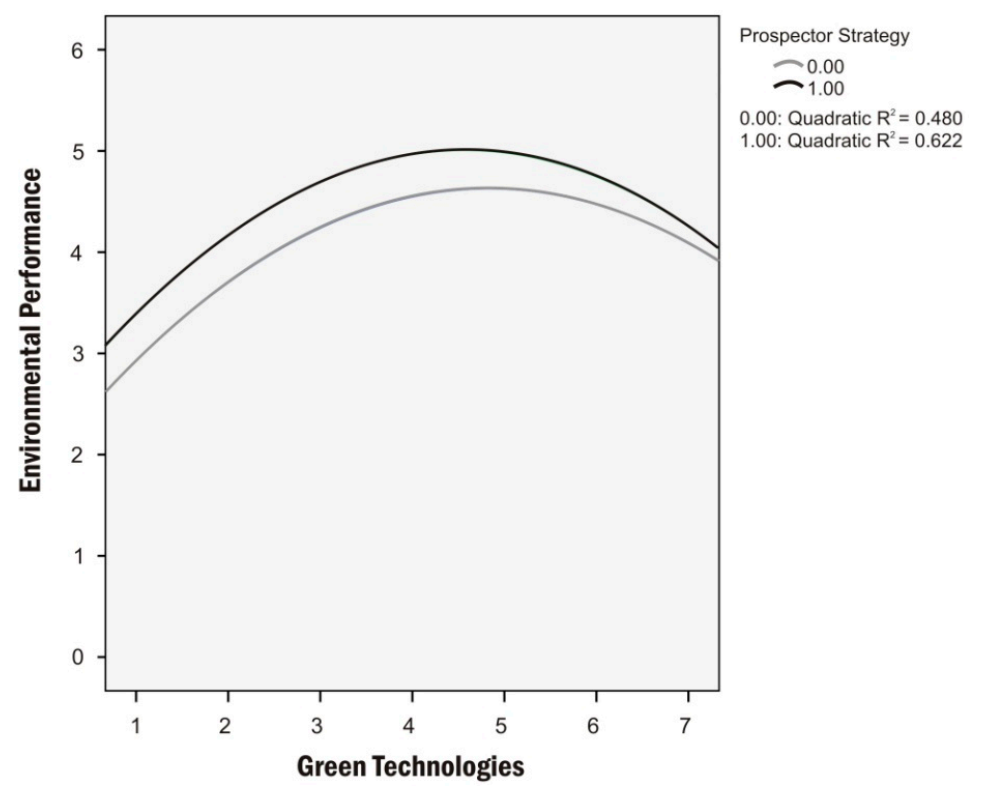

Figure 4. Moderating effect of a prospector strategy on the relationship between green technology and environmental performance.

In contrast, the adoption of a defender strategy shows low levels of efficiency in the strategic application of green technologies to improve environmental performance, regardless of the level of adoption of these green technologies, as shown in Figure 5. Therefore, these results confirm hypothesis 6 on the negative moderating effect, contrary to the findings reported for the prospector strategy (Figure 4). Again differing from the previous strategy, the difference between defender and reactor firms in the impact of green technologies on environmental performance is greater for high levels of green technology adoption.

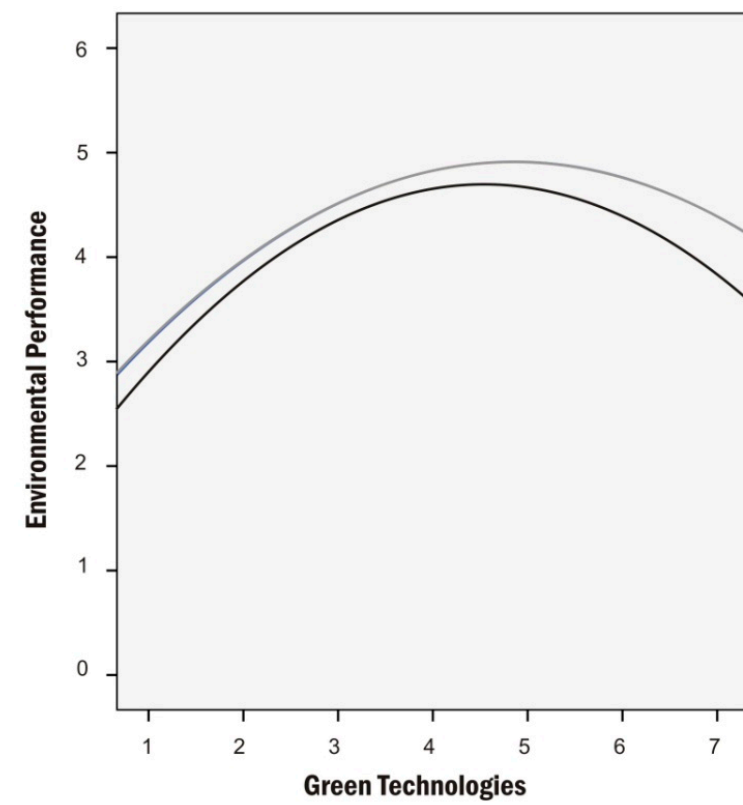

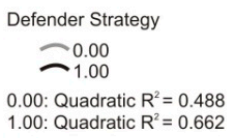

environmental performance.

Figure 6 demonstrates that analyser strategies exert a positive moderating effect on the relationship between green technology and environmental performance, from a low/medium level of green technology adoption (a threshold of 3, equivalent to a $42 \%$ degree of adoption). In addition, analyser 
firms record a maximum level of efficiency in the use of green technology superior to that of the other strategies under study (approximately 5 for prospector firms compared to 5.3 for analysers). Moreover, analyser firms report a positive relationship between green technology and environmental performance that persists up to very high levels of green technology adoption (5.5), compared with the other strategic archetypes (around 4.5; see Figures 4 and 5). That is, analyser firms achieve a significant upward and rightward shift in the inverted U-shaped relationship between green technology and environmental performance, compared to an upward or downward shift only (prospector or defender strategies, respectively).

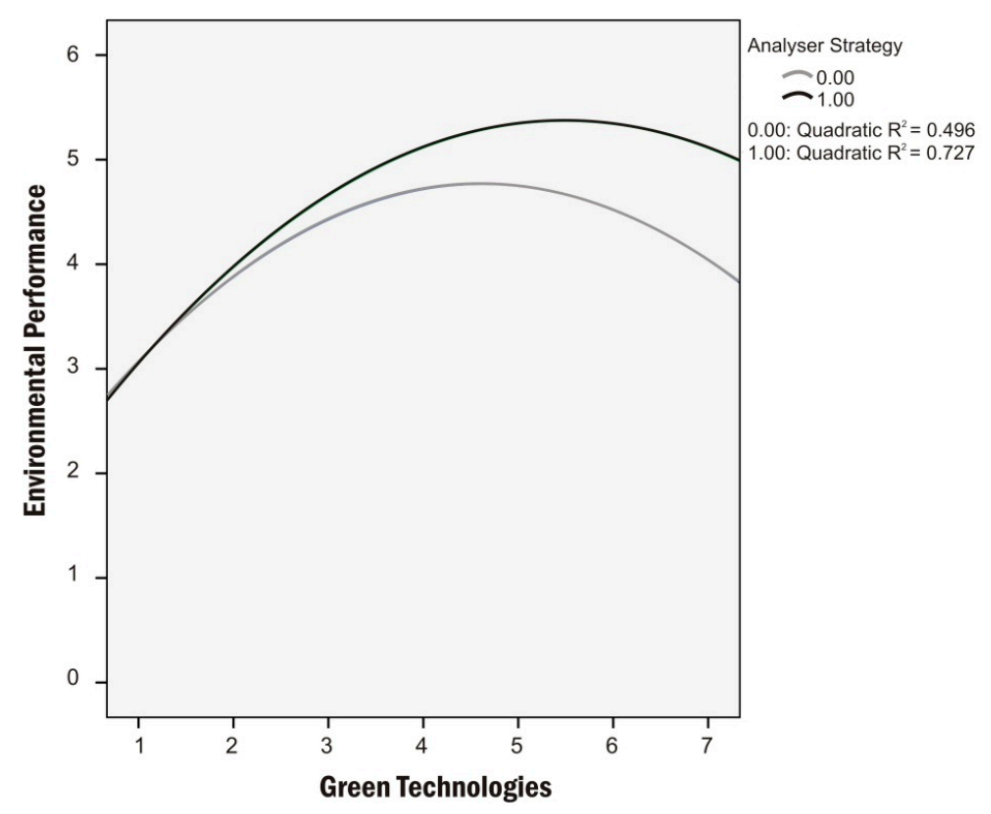

Figure 6. Moderating effect of an analyser strategy on the relationship between green technology and environmental performance.

Given the complexity of the analysis of the different moderating effects on the relationship between green technology and environmental performance, Figure 7 below summarises the patterns in the strength of the effect for low, medium and high levels of green technology adoption.

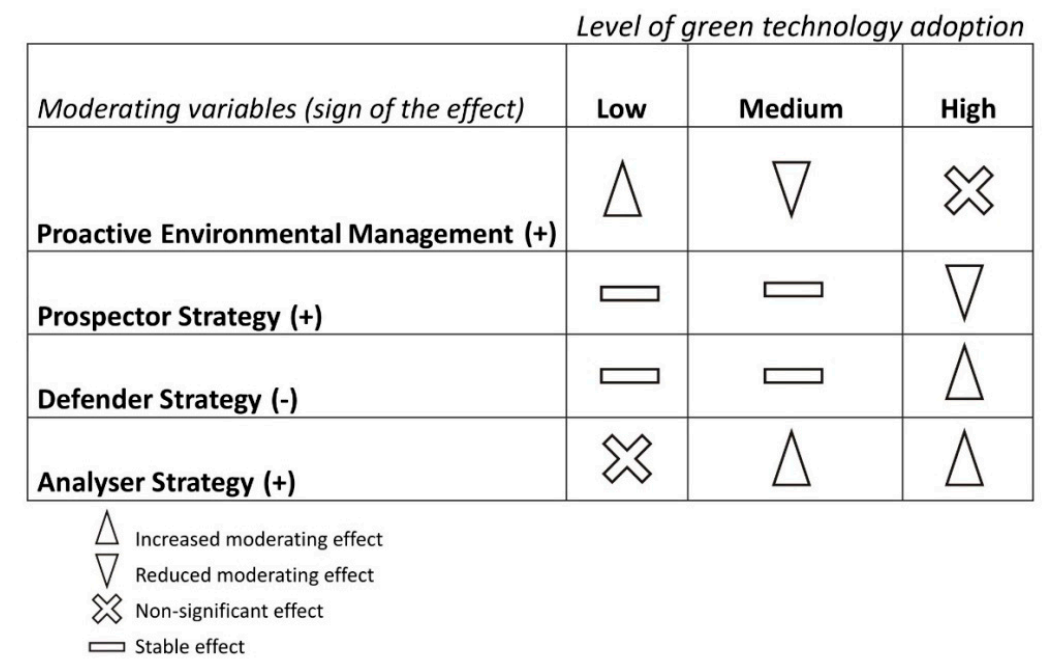

Figure 7. Strength of the moderating effects according to the level of green technology adoption. 


\section{Discussion}

In a context that requires firms to be both increasingly competitive and more environmentally-responsible, the creation of competitive advantages associated with environmental performance is paramount for the survival of firms in general [1,3], and tourism firms in particular [6,7], as the latter tend to be heavily dependent on the natural environment [29]. By applying the tenets of the NRBV [26] and the dynamic capabilities theory [27,28], this study contributes to the discussion on the topic. Specifically, it focuses on the analysis of three key factors: green technology adoption, proactive environmental management, and prospector strategy, adding to the scarce and dispersed literature that currently exists [33].

In response to growing social, cultural and legislative pressures to address environmental issues, firms have gradually increased their commitment to incorporating technological advances in their operations [3,17]. This growing trend in green technology adoption has also been observed in the tourism sector, albeit at a slower rate $[7,10]$.

This research paper is the first to explore and confirm the inverted $U$-shaped relationship between green technology and environmental performance. Some previous empirical and descriptive studies (e.g., $[23,25])$ on the impact of green technology on environmental performance have reported major challenges in terms of costs, time and managerial effort posed by green technology implementation. However, the vast majority of related empirical studies find a positive impact of green technology on environmental performance, derived from both the resulting pollution prevention measures and the efficient use of environmental resources (e.g., [64]).

The present study confirms this positive effect up to a high level of green technology adoption. In this vein, the results indicate that overinvestment in green technology may be detrimental for environmental performance. This result is in accordance with that of Chan et al. [7]) for the hospitality sector; those authors point out the importance of starting out with small-scale efficient green technology with obvious benefits in terms of reduction resource and energy waste.

Nevertheless, firms that are committed to improving their environmental performance should not content themselves with gathering the 'low hanging fruit' of green technology adoption; in order to generate and, above all, sustain a competitive advantage in environmental performance, they must create more complex, path-dependent capabilities linked to proactive environmental management and strategic approaches $[3,26,30,33]$.

The results of this study confirm the direct effects of the adoption of both proactive environmental management and a prospector strategy on environmental performance. On the one hand, proactive environmental management involves employees in the achievement of environmental objectives, as well as providing formalised structures, procedures and processes that enable firms to manage and assess their impact on the environment $[7,23,30]$. As proactive environmental management becomes more established within firms, pollution prevention and waste-reduction programmes become institutionalised [30]. On the other hand, the adoption of a prospector strategy emphasises long-term planning and the continuous exploration of and adaptation to stakeholders needs and requirements, with the environment being a crucial stakeholder to consider [26,30-32].

The implementation of a formal environmental planning, management and control system, and robust strategic positioning linked to knowledge, exploration and innovation not only have a direct impact on environmental performance; their alignment and integration with green technologies allows firms to construct more mature and sustainable environmental approaches. Complementary assets accrued through the adoption of proactive environmental management and more innovative business strategies seem to have promoted the development of distinctive skills that helped our sample of tourism firms to leverage the benefits of green technology to improve their environmental performance.

In this vein, the results confirm that the impact of green technology on environmental performance can be enhanced by a higher degree of proactive environmental management. Such management helps firms to develop the internal routines and technical knowledge that enable the efficient incorporation of green technology into existing business operations, as reported in a number of empirical analyses $[7,9,33]$. 
Proactive environmental management also helps firms to synchronise their organisational units and reorganise their processes to boost the profitability of their green technologies [33]. When a firm develops a formal proactive environmental management system, employees may also find it easier to understand the purpose of green technologies and assess them, as there is a certain level of commitment to environmental aims. Proactive environmental management also helps legitimise the firm's reputation, enabling it to extend the network of cooperating agents and maximise interchanges of specialised knowledge in order to leverage the competitive effects of green technology adoption.

However, this positive moderating effect appears to disappear at very high levels of green technology adoption. This result indicates that more extensive implementation of green technologies is detrimental to environmental performance, regardless of the firm's proactive environmental management. Moreover, it may suggest that high levels of green technology adoption could require the development of additional capabilities, managerial practices and strategies to leverage their effect on environmental performance [3,25].

When comparing the moderating effects of business strategy adoption on the curvilinear relationship between green technology and environmental performance, the results show that whereas prospector and analyser strategies exert a positive moderating effect, defender strategies have a negative effect. In fact, when green technology adoption is high, the negative moderating effect of a defender strategy on the relationship between green technology and environmental performance seems to increase, relative to firms that have not adopted any clear strategy.

In a setting where governments and institutions are committed to promoting better environmental performance, defender firms may find themselves with limited scope to compete, given the requirements of this new environment in terms of both cost efficiency (eco-efficiency) and technological advancement and innovation (eco-efficacy) [31]. The implementation of defender strategies is focused on cost-savings and efficiency, which can reduce the amount available for investment in the introduction and deployment of green technology aimed at achieving a differentiated position in environmental performance [32]. Therefore, this study shows the adoption of green technology and the implementation of a defender strategy to be alternative approaches.

More dynamic environmental strategies such as the prospector and analyser are the only ones that can help the organisation to achieve the necessary efficiency and efficacy for the deployment of green technologies $[30,31]$. In fact, the prospector strategy is the only moderating variable that increases the impact of green technology, regardless of the level of adoption. However, it should be noted that with high levels of green technology adoption, we observe a reduction in the effect of green technology on environmental performance reported by prospector firms relative to those following a reactor strategy. This effect may serve as a warning against the excessive focus of prospector strategies on continually exploring and exploiting new product and market opportunities, which can make it difficult to pay off the high costs involved in the extensive adoption of green technologies, as well as the leverage of existing practices and technologies to improve environmental performance.

In contrast, the results reveal the need for an analyser strategy to be complemented with a certain low/medium level of green technology adoption in order to impact environmental performance. Nevertheless, beyond said investment level, analyser firms appear to achieve a superior level of maximum efficiency in the application of green technology to improve environmental performance. Moreover, compared to the other strategy types under study, analyser firms are better able to leverage the positive impact of green technology on environmental performance. That is, firms adopting an analyser strategy are able to amplify the positive influence of green technology on environmental performance, shifting the optimal point of green technology adoption from a moderate to a higher level.

This strategy is the only one that seems to reduce the negative effect of high levels of green technology adoption in terms of costs and environmental impact. By learning from previous experiences of pioneering competitors in the market, the analyser strategy also reduces the risk of 'irreversible green mistakes' or potential challenges and obstacles arising from the introduction, management and application of new technologies to achieve environmental aims [60]. Therefore, although it has not 
attracted much attention in the literature, the analyser strategy seems to provide a balance between efficiency and innovation, which is crucial in economies or sectors in transition [31,60].

The importance of analyser strategies for the ability to compete against genuine prospectors in the tourism sector has been confirmed in previous studies, such as those by Hjalager [106] and Camisón and Monfort-Mir [107]. According to these authors, tourism firms are characterised by a low propensity for innovation based on internal R\&D, and for collaboration with external agents, which prompts them to engage primarily in incremental innovations and to imitate and adapt technical innovations from competitors and suppliers.

As for the control variables, this study confirms the results previously reported by Bohdanowicz [99] and Pereira-Moliner et al. [9], showing that horizontal economies of scale derived from integration and cooperation in a chain can be a major driver of environmental performance, and even more important than vertical economies of scale resulting from structural characteristics such as firm size. Since the introduction and adoption of green technologies requires a large amount of human, financial and technical resources as well as space, chain affiliation can improve the environmental performance of tourism firms $[7,9,99]$.

However, size and age do not show significant positive effects on environmental performance, as expected. These results confirm the inconsistency of the results obtained in the literature related to the effect of size (e.g., [6,48]); larger companies can achieve economies of scale, but they also have higher coordination and bureaucratic costs, and face more difficulties in developing proactive environmental strategies [6]. As with size, the effect of organisational age on performance has not been clearly established, and results vary, with some being non-significant (e.g., [1,3]).

The results also show the non-significant negative effect of non-quality costs $[100,101]$ on environmental performance. Considering the low ratio of non-quality costs commonly declared by hotel managers ( $75 \%$ report an average value of $5 \%$ non-quality costs), this non-significant effect may be due to the difficulty some managers face-linked to the reputation of the firm—in quantifying this concept or even admitting to its existence.

Finally, the results also demonstrate that hotels, tour operators and travel agencies, and transport companies are the most environmentally conscious. Although research on environmental performance in the tourism sector has mainly focused on hotel firms, it is not necessarily related to the intensity of these firms' environmental impacts in comparison to the rest of the tourism subsectors [6].

Empirical studies (e.g., $[9,29,64]$ ) confirm that hotels are increasingly bolstering their environmental commitment under growing pressure from consumers, the government and other agents in the tourism sector (such as tour operators). This concern in the hotel sector has even been reflected in the development of new market niches related to eco-tourism [6].

For their part, travel agencies are facing sweeping technological changes to the way that products are being developed and delivered, changes which force many small travel agencies to enter into alliances with other agencies or with large agency consortiums. This allows for increased buying power through shared purchases of technology, management systems and training, thus facilitating more efficient processes, quality services, and more flexibility to adapt to new product requirements of the market [108]. The central position that they hold in the tourism sector also fosters affiliations between tour operators and airlines, coach lines or other travel-related businesses [109] in order to respond to industry changes by developing unique new products that have a competitive edge in terms of price and quality.

Despite the scarce attention that it has received in the literature [6], the travel sector faces serious environmental challenges related to its heavy dependence on non-renewable natural resources. As a case in point, it is worth mentioning the airlines that are having to reduce their short- and medium-haul flights due to the important contribution to global emissions caused by their increasing popularity [110]. According to recent research (e.g., [111]), the incorporation of environmental objectives has also become more prevalent among cruise companies due to increasing public scrutiny and criticism. Therefore, within the tourism sector, hospitality, intermediaries and transport constitute dynamic, competitive 
subsectors faced with new regulations and changing customer preferences that are driving them to develop a central focus on social and environmental issues.

Overall, this study contributes original results to the scarce existing literature on the orchestration of technologies and managerial and strategic approaches to improving environmental performance in general, and in the tourism sector in particular.

\subsection{Managerial Implications}

Competing in the tourism sector increasingly requires managers to invest in acquiring or developing new technologies, strategies and practices that minimise any negative impact of their products, services and operations on the natural environment, without hindering their economic performance.

The results of this study highlight the three possible alternatives available to companies which-due to their low-level commitment to environmental challenges [33] — pursue a narrow environmental approach, adopting one related practice in isolation. These alternatives are investment in green technology adoption, the implementation of proactive environmental management or the deployment of a prospector strategy.

According to the results of the regression analysis, the adoption of green technology has a strong direct impact (high factor loading) on environmental performance. However, managers should take the reported quadratic effect of green technology on environmental performance as a warning against excessive levels of adoption of these technologies. Furthermore, they should bear in mind the limited role played by such technology in sustaining a competitive advantage over time.

As less short-term alternatives to investment in green technology, this study also confirms the direct positive effects on environmental performance of proactive environmental management and the adoption of a prospector strategy, both of which have very similar factor loadings.

However, firms seeking to achieve a higher and more sustainable level of environmental performance should ideally implement a combination of these technical and organisational innovations [25] due to the complex bundle of idiosyncratic resources and capabilities they help generate $[27,28]$. In other words, such firms should invest in a more comprehensive portfolio of environmental practices. Specifically, this study proposes and analyses two possible alternatives that involve leveraging the effect of green technology adoption on environmental performance through (1) the implementation of proactive environmental management, and (2) the adoption of a specific corporate strategy.

Proactive environmental management positively leverages the deployment of green technology to boost environmental performance. However, the significance of this positive moderating effect is contingent on the level of green technology adoption, indicating that firms that overinvest in green technology may have to make changes in the formal planning, management and assessment of these environmental technologies, and/or adopt new environmental practices, capabilities and strategies.

The comparison of the moderating effect of the three viable strategic archetypes yields some interesting results. In this regard, the adoption of a prospector strategy always enhances the relationship between green technology and environmental performance, regardless of the level of investment in green technology. However, for high levels of green technology adoption, these strategies seem to struggle to ensure the high investment costs pay off.

Conversely, defender firms show a negative moderating effect for all levels of green technology adoption. Thus, defender strategies should be avoided if firms are seeking to improve their environmental performance or to capitalise on the investment in green technology in order to redesign existing processes and products, and create new ones with minimal environmental impact and resource consumption. These results point to eco-efficacy as a sine qua non for achieving an improved competitive position in terms of environmental performance.

Lying somewhere between these two archetypes and their opposing effects is the analyser strategy, which appears to extract greater value from green technologies in terms of environmental performance, 
beyond a certain minimum level of green technology adoption. This hybrid strategy is also shown to strengthen the positive impact of green technologies on environmental performance for higher levels of green technology adoption. Finally, the results for the control variables underscore the importance of chain affiliation for achieving better environmental performance.

\subsection{Public Implications}

The choice of how to compete on environmental issues could be based on a firm's internal aspirations, as well as pressure from competitors, clients or governments. Government policy plays a crucial role in enhancing incentives for firms to invest in environmental programmes and green technology [7]. Governments thus need to better identify the needs of the new system and establish complementary measures (e.g., time-bound subsides, tax incentives and credits) to enhance firms' environmental outcomes and to reward those organisations with an innovative and proactive culture. In this vein, policymakers should consider assisting firms that have adopted a single environmental practice so that they can achieve greater environmental benefits by adopting additional ones. As for the interconnected nature of the tourism industry, policymakers also can foster the development of green cooperation agreements between firms on waste management or green purchasing through initiatives such as green supply chains $[73,109]$, by providing subsides or implementing policies.

\subsection{Limitations and Future Research}

Despite our best efforts, this study does have some limitations. On the one hand, regarding the database, the cross-sectional nature of the survey means that causality cannot be inferred; as such, it would be worth carrying out future studies using longitudinal methodologies. Longitudinal studies would also allow us to consider and analyse an alternative relationship to the one in this study, focusing on the moderating effects of higher-order capabilities, such as those typical of proactive environmental management, on the relationship between green technology adoption and environmental performance. In this sense, future studies could apply a mediation model to analyse the potential for the sustained and effective application of green technologies and associated practices to shape other organisational capabilities that, in turn, create environmental performance gains for firms [47].

Similarly, the results of this research could be reinforced in future studies by examining differences in the environmental performance of firms belonging to the same chain; by focusing on inter-chain heterogeneity in terms of use of resources, practices and capabilities, future research can seek to identify how firm-specific characteristics influence the relationship between green technology adoption and environmental performance.

Moreover, our conclusions should be extrapolated with caution, as they refer to a specific industry; therefore, while they are valuable to the Spanish tourism industry, further studies could try to confirm their relevance to other sectors and even countries. Focusing on other technological contexts could enable us to analyse the impact of different types of green technologies on environmental performance $[48,90]$ and the importance of variables such as energy costs [23]. In addition, conducting a transnational study to validate the research model in other countries would allow us to check whether variables such as proactive environmental management are influenced by cultural issues or other legal frameworks and regulatory patterns.

Regarding the measurement instruments, the scales were based on managerial self-assessment, a technique which has attracted some criticism; however, we have tried to minimise the problems of this methodology by taking a rigorous approach to data gathering, as reflected in the reliability and validity measures. Furthermore, although the items in the scales were supported by the literature, some of the final scales created for this study are new and exploratory; therefore, it may be necessary to validate and replicate them in other studies, and subsequently, to try to improve the selected items.

Future studies should analyse the impact of green technology, proactive environmental management and business strategies in terms of both social and economic benefits. They should also 
examine the correlation between these benefits and environmental ones, as these are all considered dimensions of the sustainability paradigm [13].

Finally, quality studies and techniques such as Qualitative Comparative Analysis will also allow us to better explain the complementarity between the technical and organisational innovation patterns underlying the moderating effects of the quadratic relationship under study. This analytical technique could thus provide an alternative and complementary moderation analysis of the contingent effect [112] exerted by the specific mechanisms underlying the effects of the moderating variables considered in this study, i.e., proactive environmental management and business strategies. Potential mechanisms include employees' learning and training, firms' environmental shared vision, cross-functional coordination, stakeholder engagement, control mechanisms, firms' external orientation and absorptive capacity. Such an analysis could offer interesting results about when and in which specific circumstances (considering alternative but equifinal combinations of independent moderating mechanisms) green technology adoption yields the maximum impact on environmental performance.

Funding: This research was funded by the Ministry of Science, Innovation, and Universities and the State Research Agency (AEI), and co-funded by the European Regional Development Fund (FEDER), project reference ECO2016-76796-P. Support was also provided by Universitat Jaume I, reference+UJI-A2017-04, and USE project number 3665/18.

Conflicts of Interest: The authors declare no conflict of interest. The funders had no role in the design of the study; in the collection, analyses, or interpretation of data; in the writing of the manuscript, or in the decision to publish the results.

\section{References}

1. Fraj, E.; Matute, J.; Melero, I. Environmental strategies and organizational competitiveness in the hotel industry: The role of learning and innovation as determinants of environmental success. Tour. Manag. 2015, 46, 30-42. [CrossRef]

2. Molina-Azorín, J.F.; Claver-Cortés, E.; López-Gamero, M.D.; Tarí, J.J. Green management and financial performance: A literature review. Manag. Decis. 2009, 47, 1080-1100. [CrossRef]

3. Wang, Y.; Chen, Y.; Benitez-Amado, J. How information technology influences environmental performance: Empirical evidence from China. Int. J. Inf. Manag. 2015, 35, 160-170. [CrossRef]

4. Lenzen, M.; Sun, Y.Y.; Faturay, F.; Ting, Y.P.; Geschke, A.; Malik, A. The carbon footprint of global tourism. Nat. Clim. Chang. 2018, 8, 522. [CrossRef]

5. Chen, S.; Chen, H.H.; Zhang, K.Q.; Xu, X.L. A comprehensive theoretical framework for examining learning effects in green and conventionally managed hotels. J. Clean. Prod. 2018, 174, 1392-1399. [CrossRef]

6. Aragon-Correa, J.A.; Martin-Tapia, I.; de la Torre-Ruiz, J. Sustainability issues and hospitality and tourism firms' strategies: Analytical review and future directions. Int. J. Contemp. Hosp. Manag. 2015, 27, 498-522. [CrossRef]

7. Chan, E.S.W.; Okumus, F.; Chan, W. Barriers to Environmental Technology Adoption in Hotels. J. Hosp. Tour. Res. 2018, 42, 829-852. [CrossRef]

8. Molina-Azorín, J.F.; Tarí, J.J.; Pereira-Moliner, J.; López-Gamero, M.D.; Pertusa-Ortega, E.M. The effects of quality and environmental management on competitive advantage: A mixed methods study in the hotel industry. Tour. Manag. 2015, 50, 41-54. [CrossRef]

9. Pereira-Moliner, J.; Font, X.; Molina-Azorin, J.F.; José Tari, J.; Lopez-Gamero, M.D.; Pertusa-Ortega, E.M. The holy grail:Environmental management, competitive advantage and business performance in the Spanish hotel industry. Int. J. Contemp. Hosp. Manag. 2015, 27, 714-738. [CrossRef]

10. Ayuso, S. Adoption of voluntary environmental tools for sustainable tourism: Analysing the experience of Spanish hotels. Corp. Soc. Responsib. Environ. Manag. 2006, 13, 207-220. [CrossRef]

11. Zhu, H.; Zhang, J.; Zhao, L.; Jin, S. Low carbon transition and sustainable development path of tourism industry. In IOP Conference Series: Earth and Environmental Science; IOP Publishing: Bristol, UK, 2017; p. 64.

12. WBCSD. Eco-Efficiency. Creating More Value with Less Impact; World Business Council for Sustainable Development: Geneva, Switzerland, 2000; Volume 32.

13. Elkington, J. Towards the sustainable corporation: Win-win-win business strategies for sustainable development. Calif. Manag. Rev. 1994, 36, 90-100. [CrossRef] 
14. Chen, Y.S.; Chang, C.H. Enhance green purchase intentions: The roles of green perceived value, green perceived risk, and green trust. Manag. Decis. 2012, 50, 502-520. [CrossRef]

15. Kang, K.H.; Stein, L.; Heo, C.Y.; Lee, S. Consumers' willingness to pay for green initiatives of the hotel industry. Int. J. Hosp. Manag. 2012, 31, 564-572. [CrossRef]

16. Bengtsson, F.; Ågerfalk, P.J. Information technology as a change actant in sustainability innovation: Insights from Uppsala. J. Strateg. Inf. Syst. 2011, 20, 96-112. [CrossRef]

17. Watson, R.T.; Boudreau, M.C.; Chen, A.J. Information systems and environmentally sustainable development: Energy informatics and new directions for the IS community. MIS Q. 2010, 34, 23-38. [CrossRef]

18. Elliot, S. Transdisciplinary perspectives on environmental sustainability: A resource base and framework for IT-enabled business transformation. MIS Q. 2011, 35, 197-236. [CrossRef]

19. Seidel, S.; Recker, J.; Vom Brocke, J. Sensemaking and sustainable practicing: Functional affordances of information systems in green transformations. MIS Q. 2013, 37, 1275-1299. [CrossRef]

20. Dao, V.; Langella, I.; Carbo, J. From green to sustainability: Information Technology and an integrated sustainability framework. J. Strateg. Inf. Syst. 2011, 20, 63-79. [CrossRef]

21. Petrini, M.; Pozzebon, M. Managing sustainability with the support of business intelligence: Integrating socio-environmental indicators and organisational context. J. Strateg. Inf. Syst. 2009, 18, 178-191. [CrossRef]

22. Mithas, S.; Khuntia, J.; Roy, P.K. Green information technology, energy efficiency, and profits: Evidence from an emerging economy. In International Conference on Information Systems (ICIS); ICIS: St. Louis, MO, USA, 2010; p. 11.

23. Stucki, T. Which firms benefit from investments in green energy technologies? The effect of energy costs. Res. Pol. 2019, 48, 546-555. [CrossRef]

24. Przychodzen, W.; Gómez-Bezares, F.; Przychodzen, J. Green information technologies practices and financial performance-the empirical evidence from German publicly traded companies. J. Clean. Prod. 2018, 201, 570-579. [CrossRef]

25. Hottenrott, H.; Rexhäuser, S.; Veugelers, R. Organisational change and the productivity effects of green technology adoption. Resour. Energy Econ. 2016, 43, 172-194. [CrossRef]

26. Hart, S.L. A natural-resource-based view of the firm. Acad. Manag. Rev. 1995, 20, 986-1014. [CrossRef]

27. Teece, D.J.; Pisano, G.; Shuen, A. Dynamic capabilities and strategic management. Strateg. Manag. J. 1997, 18, 509-533. [CrossRef]

28. Teece, D.J. Explicating dynamic capabilities: The nature and microfoundations of (sustainable) enterprise performance. Strateg. Manag. J. 2007, 28, 1319-1350. [CrossRef]

29. López-Gamero, M.D.; Molina-Azorín, J.F.; Claver-Cortés, E. The whole relationship between environmental variables and firm performance: Competitive advantage and firm resources as mediator variables. J. Environ. Manag. 2009, 90, 3110-3121. [CrossRef] [PubMed]

30. Passetti, E.; Tenucci, A. Eco-efficiency measurement and the influence of organisational factors: Evidence from large Italian companies. J. Clean. Prod. 2016, 122, 228-239. [CrossRef]

31. Tang, Z.; Tang, J. Entrepreneurial orientation and SME performance in China's changing environment: The moderating effects of strategies. Asia Pac. J. Manag. 2012, 29, 409-431. [CrossRef]

32. Aragón-Correa, J.A. Strategic proactivity and firm approach to the natural environment. Acad. Manag. J. 1998, 41, 556-567. [CrossRef]

33. Ozusaglam, S.; Kesidou, E.; Wong, C.Y. Performance effects of complementarity between environmental management systems and environmental technologies. Int. J. Prod. Econ. 2018, 197, 112-122. [CrossRef]

34. INE. Cuenta Satélite del Turismo de España (CSTE). Base 2010 Serie 2010-2017. Available online: https://www.ine.es/dyngs/INEbase/es/operacion.htm?c=Estadistica_C\&cid=1254736169169\&menu= ultiDatos\&idp=1254735576863 (accessed on 1 August 2019).

35. Fernando, Y.; Jabbour, C.J.C.; Wah, W.X. Pursuing green growth in technology firms through the connections between environmental innovation and sustainable business performance: Does service capability matter? Resour. Conserv. Recycl. 2019, 141, 8-20. [CrossRef]

36. Amui, L.B.L.; Jabbour, C.J.C.; de Sousa Jabbour, A.B.L.; Kannan, D. Sustainability as a dynamic organizational capability: A systematic review and a future agenda toward a sustainable transition. J. Clean. Prod. 2017, 142, 308-322. [CrossRef] 
37. Ong, T.S.; Lee, A.S.; The, B.H.; Magsi, H.B. Environmental innovation, environmental performance and financial performance: Evidence from Malaysian environmental proactive firms. Sustainability 2019, 11, 3494. [CrossRef]

38. Suarez-Perales, I.; Garces-Ayerbe, C.; Rivera-Torres, P.; Suarez-Galvez, C. Is strategic proactivity a driver of an environmental strategy? Effects of innovation and internationalization leadership. Sustainability 2017, 9, 1870. [CrossRef]

39. Ryszko, A. Proactive environmental strategy, technological eco-innovation and firm performance-case of Poland. Sustainability 2016, 8, 156. [CrossRef]

40. Grant, R.M. The resource-based theory of competitive advantage: Implications for strategy formulation. Calif. Manag. Rev. 1991, 33, 114-135. [CrossRef]

41. Majumdar, S.K.; Marcus, A.A. Rules versus discretion: The productivity consequences of flexible regulation. Acad. Manag. J. 2001, 44, 170-179.

42. Mousavi, S.; Bossink, B.; van Vliet, M. Dynamic capabilities and organizational routines for managing innovation towards sustainability. J. Clean. Prod. 2018, 203, 224-239. [CrossRef]

43. Dangelico, R.M.; Pujari, D.; Pontrandolfo, P. Green Product Innovation in Manufacturing Firms: A Sustainability-Oriented Dynamic Capability Perspective. Bus. Strateg. Environ. 2017, 26, 490-506. [CrossRef]

44. Russo, M.V. Explaining the impact of ISO 14001 on emission performance: A dynamic capabilities perspective on process and learning. Bus. Strateg. Environ. 2009, 18, 307-319. [CrossRef]

45. Barreto, I. Dynamic capabilities: A review of past research and an agenda for the future. J. Manag. 2010, 36, 256-280. [CrossRef]

46. Dangelico, R.M. Green product innovation: Where we are and where we are going. Bus. Strateg. Environ. 2016, 25, 560-576. [CrossRef]

47. Benitez-Amado, J.; Walczuch, R.M. Information technology, the organizational capability of proactive corporate environmental strategy and firm performance: A resource-based analysis. Eur. J. Inf. Syst. 2012, 21, 664-679. [CrossRef]

48. Nath, P.; Ramanathan, R. Environmental management practices, environmental technology portfolio, and environmental commitment: A content analytic approach for UK manufacturing firms. Int. J. Prod. Econ. 2016, 171, 427-437. [CrossRef]

49. Shrivastava, P. Environmental technologies and competitive advantage. Strateg. Manag. J. 1995, 16, $183-200$. [CrossRef]

50. Guziana, B. Is the Swedish environmental technology sector 'green'? J. Clean. Prod. 2011, 19, 827-835. [CrossRef]

51. Chan, E.S.; Okumus, F.; Chan, W. The applications of environmental technologies in hotels. J. Hosp. Mark. Manag. 2017, 26, 23-47. [CrossRef]

52. Testa, F.; Rizzi, F.; Daddi, T.; Gusmerotti, N.M.; Frey, M.; Iraldo, F. EMAS and ISO 14001: The differences in effectively improving environmental performance. J. Clean. Prod. 2014, 68, 165-173. [CrossRef]

53. Camisón, C. Effects of coercive regulation versus voluntary and cooperative auto-regulation on environmental adaptation and performance: Empirical evidence in Spain. Eur. Manag. J. 2010, 28, 346-361. [CrossRef]

54. Aragón-Correa, J.A.; Sharma, S. A contingent resource-based view of proactive corporate environmental strategy. Acad. Manag. Rev. 2003, 28, 71-88. [CrossRef]

55. Schrettle, S.; Hinz, A.; Scherrer-Rathje, M.; Friedli, T. Turning sustainability into action: Explaining firms' sustainability efforts and their impact on firm performance. I. J. Prod. Econ. 2014, 147, 73-84. [CrossRef]

56. Powell, T.C.; Dent-Micallef, A. Information technology as competitive advantage: The role of human, business, and technology resources. Strateg. Manag. J. 1997, 18, 375-405. [CrossRef]

57. Ray, G.; Muhanna, W.A.; Barney, J.B. Information technology and the performance of the customer service process: A resource-based analysis. MIS Q. 2005, 29, 625-652. [CrossRef]

58. Russo, M.V.; Fouts, P.A. A resource-based perspective on corporate environmental performance and profitability. Acad. Manag. J. 1997, 40, 534-559.

59. Hart, S.L.; Dowell, G. Invited editorial: A natural-resource-based view of the firm: Fifteen years after. J. Manag. 2011, 37, 1464-1479. [CrossRef]

60. Miles, R.; Snow, C.C. Organizational Structure, Strategy and Process; McGraw-Hill: New York, NY, USA, 1978.

61. De Stefano, M.C.; Montes-Sancho, M.J.; Busch, T. A natural resource-based view of climate change: Innovation challenges in the automobile industry. J. Clean. Prod. 2016, 139, 1436-1448. [CrossRef] 
62. Kunapatarawong, R.; Martínez-Ros, E. Towards green growth: How does green innovation affect employment? Res. Pol. 2016, 45, 1218-1232. [CrossRef]

63. Mejia, C. Influencing green technology use behavior in the hospitality industry and the role of the "green champion". J. Hosp. Mark. Manag. 2019, 28, 538-557. [CrossRef]

64. Molina-Azorín, J.F.; Claver-Cortés, E.; Pereira-Moliner, J.; Tarí, J.J. Environmental practices and firm performance: An empirical analysis in the Spanish hotel industry. J. Clean. Prod. 2009, 17, 516-524. [CrossRef]

65. Ghisetti, C.; Rennings, K. Environmental innovations and profitability: How does it pay to be green? An empirical analysis on the German innovation survey. J. Clean. Prod. 2014, 75, 106-117. [CrossRef]

66. Kong, T.; Feng, T.; Ye, C. Advanced manufacturing technologies and green innovation: The role of internal environmental collaboration. Sustainability 2016, 8, 1056. [CrossRef]

67. Comoglio, C.; Botta, S. The use of indicators and the role of environmental management systems for environmental performances improvement: A survey on ISO 14001 certified companies in the automotive sector. J. Clean. Prod. 2012, 20, 92-102. [CrossRef]

68. Rondinelli, D.; Vastag, G. Panacea, common sense, or just a label: The value of ISO 14001 environmental management systems. Eur. Manag. J. 2000, 18, 499-510. [CrossRef]

69. Sarkis, J.; Gonzalez-Torre, P.; Adenso-Diaz, B. Stakeholder pressure and the adoption of environmental practices: The mediating effect of training. J. Oper. Manag. 2010, 28, 163-176. [CrossRef]

70. Magsi, H.B.; Ong, T.S.; Ho, J.A.; Hassan, A.F.S. Organizational culture and environmental performance. Sustainability 2018, 10, 1-17.

71. Singjai, K.; Winata, L.; Kummer, T.F. Green initiatives and their competitive advantage for the hotel industry in developing countries. Int. J. Hosp. Manag. 2018, 75, 131-143. [CrossRef]

72. Chan, E.S.; Hawkins, R. Application of EMSs in a hotel context: A case study. Int. J. Hosp. Manag. 2012, 31, 405-418. [CrossRef]

73. Lee, D.H. Implementation of collaborative activities for sustainable supply chain innovation: An analysis of the firm size effect. Sustainability 2019, 11, 3026. [CrossRef]

74. Camisón, C.; Forés, B. Is tourism firm competitiveness driven by different internal or external specific factors: New empirical evidence from Spain. Tour. Manag. 2015, 48, 477-499. [CrossRef]

75. Chan, E.S.W.; Wong, S.C.K. Motivations for ISO 14001 in the hotel industry. Tour. Manag. 2006, 27, 481-492. [CrossRef]

76. Haverkamp, D.J.; Bremmers, H.; Omta, O. Stimulating environmental management performance: Towards a contingency approach. Br. Food J. 2010, 112, 1237-1251. [CrossRef]

77. Wagner, M. How to reconcile environmental and economic performance to improve corporate sustainability: Corporate environmental strategies in the European paper industry. J. Environ. Manag. 2005, 76, 105-118. [CrossRef] [PubMed]

78. Diana, G.C.; Jabbour, C.J.C.; de Sousa Jabbour, A.B.L.; Kannan, D. Putting environmental technologies into the mainstream: Adoption of environmental technologies by medium-sized manufacturing firms in Brazil. J. Clean. Prod. 2017, 142, 4011-4018. [CrossRef]

79. Bloom, N.; Genakos, C.; Martin, R.; Sadun, R. Modern management: Good for the environment or just hot air? Econ. J. 2010, 120, 551-572. [CrossRef]

80. Zhou, K.Z.; Wu, F. Technological capability, strategic flexibility, and product innovation. Strateg. Manag. J. 2010, 31, 547-561. [CrossRef]

81. Fernando, Y.; Wah, W.X.; Shaharudin, M.S. Does a firm's innovation category matter in practising eco-innovation? Evidence from the lens of Malaysia companies practicing green technology. J. Manuf. Technol. Manag. 2016, 27, 208-233. [CrossRef]

82. Menguc, B.; Ozanne, L.K. Challenges of the "green imperative": A natural resource-based approach to the environmental orientation-business performance relationship. J. Bus. Res. 2005, 58, 430-438. [CrossRef]

83. Vachon, S.; Klassen, R.D. Extending green practices across the supply chain: The impact of upstream and downstream integration. Int. J. Oper. Prod. Manag. 2006, 26, 795-821. [CrossRef]

84. Ortiz-de-Mandojana, N.; Aragón-Correa, J.A.; Delgado-Ceballos, J.; Ferrón-Vílchez, V. The effect of director interlocks on firms' adoption of proactive environmental strategies. Corp. Gov. Int. Rev. 2012, 20, 164-178. [CrossRef] 
85. Cohen, W.M.; Levinthal, D.A. Absorptive capacity: A new perspective on learning and innovation. Adm. Sci. Q. 1990, 35, 128-152. [CrossRef]

86. Vickers, I. Cleaner Production and Organizational Learning. Technol. Anal. Strateg. Manag. 1999, 11, 75-94. [CrossRef]

87. Sharma, S.; Vredenburg, H. Proactive corporate environmental strategy and the development of competitively valuable organizational capabilities. Strateg. Manag. J. 1998, 19, 729-753. [CrossRef]

88. Christmann, P. Effects of "best practices" of environmental management on cost advantage: The role of complementary assets. Acad. Manag. J. 2000, 43, 663-680.

89. Carmona-Moreno, E.; Céspedes-Lorente, J.; De Burgos-Jiménez, J. Environmental strategies in Spanish hotels: Contextual factors and performance. Serv. Ind. J. 2004, 24, 101-130. [CrossRef]

90. Klassen, R.D.; Whybark, D.C. The impact of environmental technologies on manufacturing performance. Acad. Manag. J. 1999, 42, 599-615.

91. Teece, D.J. Profiting from technological innovation: Implications for integration, collaboration, licensing and public policy. Res. Policy 1986, 15, 285-305. [CrossRef]

92. Dillman, D.A. Mail and Telephone Surveys: The Total Design Method; John Wiley \& Sons: New York, NY, USA, 1978.

93. Podsakoff, P.M.; Organ, D.W. Self-reports in organizational research: Problems and prospects. J. Manag. 1986, 12, 531-544. [CrossRef]

94. Podsakoff, P.M.; MacKenzie, S.B.; Lee, J.Y.; Podsakoff, N.P. Common method biases in behavioral research: A critical review of the literature and recommended remedies. J. Appl. Psychol. 2003, 88, 879-903. [CrossRef] [PubMed]

95. Siemsen, E.; Roth, A.; Oliveira, P. Common method bias in regression models with linear, quadratic, and interaction effects. Organ. Res. Methods 2010, 13, 456-476. [CrossRef]

96. Zhu, Q.; Sarkis, J. The moderating effects of institutional pressures on emergent green supply chain practices and performance. Intern. J. Prod. Res. 2007, 45, 4333-4355. [CrossRef]

97. Snow, C.C.; Hrebiniak, L.G. Strategy, distinctive competence, and organizational performance. Adm. Sci. Q. 1980, 25, 317-336. [CrossRef]

98. King, A.; Lenox, M. Exploring the locus of profitable pollution reduction. Manag. Sci. 2002, 48, $289-299$. [CrossRef]

99. Bohdanowicz, P. European hoteliers' environmental attitudes: Greening the business. Cornell Hotel Restaur. Adm. Q. 2005, 46, 188-204. [CrossRef]

100. Harrignton, H.J. Poor-Quality Cost; ASQC Press: Milwaukee, VI, USA, 1987.

101. Crosby, P.B. Quality Is Free. The Art of Making Quality Certain; McGraw-Hill: New York, NY, USA, 1979.

102. Hair, J.F.; Anderson, R.E.; Tatham, R.L.; Black, W.C. Multivariate Data Analysis, 5th ed.; Prentice Hall, Englewood Cliffs: Upper Saddle River, NJ, USA, 1998.

103. Churchill, G.A., Jr. A paradigm for developing better measures of marketing constructs. J. Mark. Res. 1979, 16, 64-73. [CrossRef]

104. Cohen, P.; Cohen, J.; West, S.G.; Aiken, L.S. Applied Multiple Regression/Correlation Analysis for the Behavioral Sciencel, 3rd ed.; Lawrence Erlbaum: Mahwah, NJ, USA, 2003.

105. Aiken, L.S.; West, S.G.; Reno, R.R. Multiple Regression: Testing and Interpreting Interactions; Sage: Thousand Oaks, CA, USA, 1991.

106. Hjalager, A.M. Repairing innovation defectiveness in tourism. Tour. Manag. 2002, 23, 465-474. [CrossRef]

107. Camisón, C.; Monfort-Mir, V.M. Measuring innovation in tourism from the Schumpeterian and the dynamic-capabilities perspectives. Tour. Manag. 2012, 33, 776-789. [CrossRef]

108. Bagur-Femenias, L.; Llach, J.; del Mar Alonso-Almeida, M. Is the adoption of environmental practices a strategical decision for small service companies? An empirical approach. Manag. Decis. 2013, 51, 41-62. [CrossRef]

109. Adriana, B. Environmental supply chain management in tourism: The case of large tour operators. J. Clean. Prod. 2009, 17, 1385-1392. [CrossRef]

110. Cowper-Smith, A.; de Grosbois, D. The adoption of corporate social responsibility practices in the airline industry. J. Sustain. Tour. 2011, 19, 59-77. [CrossRef] 
111. De Grosbois, D. Corporate social responsibility reporting in the cruise tourism industry: A performance evaluation using a new institutional theory based model. J. Sustain. Tour. 2016, 24, 245-269. [CrossRef]

112. Woodside, A.G. Moving beyond multiple regression analysis to algorithms: Calling for adoption of a paradigm shift from symmetric to asymmetric thinking in data analysis and crafting theory. J. Bus. Res. 2013, 66, 463-472. [CrossRef] 